Article

\title{
Evaluation of a New Generation of Coated Fertilizers to Reduce the Leaching of Mineral Nutrients and Greenhouse Gas $\left(\mathrm{N}_{2} \mathrm{O}\right)$ Emissions
}

\author{
Fatima Zahra Benlamlih ${ }^{1}$, Mohammed S. Lamhamedi ${ }^{2}$, Steeve Pepin ${ }^{1, *(D)}$, Lahcen Benomar ${ }^{3}$ and \\ Younès Messaddeq ${ }^{4}$
}

1 Centre de Recherche et d'Innovation sur les Végétaux, Faculté des Sciences de l'Agriculture et de l'Alimentation, Université Laval, 2480 boul., Hochelaga, Québec, QC G1V 0A6, Canada; f.benlamlih@gmail.com

2 Ministère des Forêts, de la Faune et des Parcs, Direction de la Recherche Forestière, 2700 rue Einstein, Québec, QC G1P 3W8, Canada; mohammed.lamhamedi@mffp.gouv.qc.ca

3 Forest Research Institute, Université du Québec en Abitibi-Témiscamingue (UQAT), 445 boul. de l'Université, Rouyn-Noranda, QC J9X 5E4, Canada; Lahcen.Benomar2@uqat.ca

4 Centre d'Optique, Photonique et Laser (COPL), Université Laval, 2375 rue de la Terrasse, Québec, QC G1V 0A6, Canada; younes.messaddeq@copl.ulaval.ca

* Correspondence: Steeve.Pepin@fsaa.ulaval.ca

Citation: Benlamlih, F.Z.;

Lamhamedi, M.S.; Pepin, S.; Benomar, L.; Messaddeq, Y. Evaluation of a New Generation of Coated Fertilizers to Reduce the Leaching of Mineral Nutrients and Greenhouse Gas $\left(\mathrm{N}_{2} \mathrm{O}\right)$ Emissions. Agronomy 2021, 11, 1129 https://doi.org/10.3390/agronomy 11061129

Academic Editors: Germán Tortosa, María J. Delgado, Socorro Mesa and Eulogio J. Bedmar

Received: 17 April 2021

Accepted: 28 May 2021

Published: 1 June 2021

Publisher's Note: MDPI stays neutra with regard to jurisdictional claims in published maps and institutional affiliations.

Copyright: (c) 2021 by the authors. Licensee MDPI, Basel, Switzerland. This article is an open access article distributed under the terms and conditions of the Creative Commons Attribution (CC BY) license (https:// creativecommons.org/licenses/by/ $4.0 /)$

\begin{abstract}
The increased use of fertilizers in agriculture and forest and horticulture nurseries contributes to the pollution of water resources and greenhouse gas emissions. The objective of this study is to evaluate a new generation of fertilizers coated with new biodegradable polymers in terms of physical quality, release kinetics, and their effect on reducing nitrate leaching and $\mathrm{N}_{2} \mathrm{O}$ emissions and compare them to uncoated fertilizers (Urea, monoammonium phosphate (MAP), and $\mathrm{KCl}$ ) having the same mineral nutrient concentration. In a peat-based substrate, the release of mineral nutrients was similar in both types of fertilizer. Two hours after application, Urea released $34 \%$ more urea than Biodrix $\mathrm{N}$, the difference disappearing after one day. The leaching of cumulative ammonium nitrogen after 20 days was reduced by $40 \%$ and $26 \%$ respectively by Aminaex and Biodrix $N$ compared to Urea. In a peat-based substrate containing 30\% $(v / v)$ of compost, the cumulative nitrate leaching was reduced by $54 \%$ by Biodrix $\mathrm{N}$ and by $41 \%$ by Aminaex compared to Urea. The highest average $\mathrm{N}_{2} \mathrm{O}$ flux was observed on the first day for Urea, whereas for Aminaex and Biodrix $\mathrm{N}_{2} \mathrm{~N}_{2} \mathrm{O}$ emissions increased on the third day, reaching a peak of efflux on day 10. A 10-day delay of the $\mathrm{N}_{2} \mathrm{O}$ efflux emissions and a longer period of emissions were observed in treatments containing Aminaex and Biodrix $\mathrm{N}$ compared to Urea. Cumulative $\mathrm{N}_{2} \mathrm{O}$ efflux was 142,154 , and $171 \mathrm{mg} \mathrm{m}^{-2}$, respectively, for Urea, Aminaex, and Biodrix $\mathrm{N}$ over a 20-day period. These new biodegradable polymer-coated nitrogen fertilizers can reduce mineral nutrient leaching in the event of heavy rainfall and lower maximum $\mathrm{N}_{2} \mathrm{O}$ emissions in comparison with conventional nitrogen sources.
\end{abstract}

Keywords: coated fertilizers; leaching; greenhouse gases; $\mathrm{N}_{2} \mathrm{O}$ emissions; fertilization; climate change

\section{Introduction}

Global agriculture is currently facing a major challenge: ensuring food security to meet the growing demand for agricultural products while limiting the negative effects of agriculture on the environment [1]. In recent decades, the agricultural sector has consumed increasingly large volumes of fertilizer to boost crop yields. In fact, global demand for key fertilizers $(\mathrm{N}, \mathrm{P}, \mathrm{K})$ has increased annually by $1.9 \%$ on average since 2015 and is estimated to reach 201.7 million tons in 2020 [2].

Synthetic fertilizers are currently used in every intensive agricultural production system, namely field crops, vegetable crops, horticulture, arboriculture, and horticultural, ornamental, and forestry nurseries [3-5]. Nitrogen fertilizers are the most widely used in 
the world, as nitrogen is a major mineral nutrient and is a limiting factor of growth, plant development, and the achievement of the anticipated yields [6]. The application of nitrogen fertilizers $(\mathrm{N})$ has rapidly increased in recent decades. For example, according to Statistics Canada [7], urea production increased by 18.2\% in 2016-2017 in Canada compared to the previous year.

The increased application of fertilizers has been known to have a negative impact on the environment and could exacerbate the effects of climate change. That is in part because nitrogen fertilizers are likely to release nitrous oxide $\left(\mathrm{N}_{2} \mathrm{O}\right)$ through denitrification. Nitrous oxide is a very powerful greenhouse gas, almost 300 times more than the $\mathrm{CO}_{2}$ found in the atmosphere [8]. Agricultural soils are recognized as the main source of anthropogenic $\mathrm{N}_{2} \mathrm{O}$ emissions, contributing to about $60 \%$ of global anthropogenic $\mathrm{N}_{2} \mathrm{O}$ emissions [9]. In addition, nearly 3\% of Canada's greenhouse gas (GHG) emissions come directly from agricultural $\mathrm{N}_{2} \mathrm{O}$ emissions [10]. These emissions are mainly caused by the application of nitrogen fertilizers (N) since approximately $1-4 \%$ of the nitrogen applied to the soil is lost as $\mathrm{N}_{2} \mathrm{O}$ [9]. Other studies have shown that nearly $40-70 \%$ of nitrogen fertilizers applied are lost in the environment either by volatilization, denitrification, or leaching of nitrates $\left(\mathrm{NO}_{3}{ }^{-}\right)$, which further aggravates groundwater pollution and the quality of surface water [11]. Mineral nutrient leaching, particularly nitrates, is a global issue because of its contribution to groundwater pollution and the contamination of drinking water in wells. A study conducted in five regions of Quebec on groundwater sampling in potato-growing areas indicates that nitrate concentrations were above the drinking water threshold of $10 \mathrm{mg}\left(\mathrm{N}-\mathrm{NO}_{3}\right) \mathrm{L}^{-1}$ in $40 \%$ of wells [12].

The excessive application of nitrogen and phosphoric fertilizers on agricultural lands leads to the loss of a large fraction of these elements in runoff water or by leaching and percolation to the groundwater. This results in the proliferation of algae and aquatic plants in rivers and lakes, causing eutrophication, a phenomenon known to negatively impact drinking water quality and treatment, animal and human health, and the aquatic ecosystem $[13,14]$.

Several studies have focused on slow-release fertilizers as a solution to reduce groundwater contamination, decrease GHG emissions and mitigate the effects of climate change [15-17]. These studies usually address fertilizer coatings composed of various materials such as sulfur, waxes, polyethylene, synthetic polymers, etc., and most of these materials are non-degradable, expensive, and toxic to soil microbial activity [18]. In contrast, biodegradable plant polymers have shown better-controlled release [18,19]. Such polymers represent a better fertilizer coating alternative to ensure sustainable agriculture is conducted with respect to the environment.

The overall objective of this study is to evaluate a new generation of controlledrelease fertilizers, coated with new biodegradable polymers, as an innovative solution to improve mineral nutrient utilization efficiency and reduce nitrogen leaching and oxide $\left(\mathrm{N}_{2} \mathrm{O}\right)$ emissions. The specific objectives are $(i)$ to assess the coating homogeneity of four coated fertilizers and controls (uncoated fertilizers) using several specific variables of their physical characteristics; (ii) to determine the release kinetics of the mineral nutrients of fertilizers with and without coating in a solution and a peat-based substrate; (iii) quantify the effect of the new generation of coated fertilizers on $\mathrm{N}$ leaching and $\mathrm{N}_{2} \mathrm{O}$ emission reductions.

\section{Materials and Methods}

For this study, four different fertilizers were coated with new biodegradable polymers under laboratory conditions (Younès Messaddeq and collaborators, personal communications): two urea-based nitrogen fertilizers (Aminaex and Biodrix N (46-0-0)), one phosphate fertilizer (Biodrix P (11-48-0)) and one potassium fertilizer (Biodrix K (0-0-60)). The coatings are composed of biodegradable polymers specifically designed to reduce $\mathrm{N}_{2} \mathrm{O}$ emissions and leaching. The exact composition of these polymers is not specified to protect trade secrets for patent purposes. Control treatments are conventional uncoated fertilizers with the 
same concentration of mineral nutrients as the coated fertilizers: urea (Urea), phosphorus (MAP), and potassium (KCl).

\subsection{Substrate Characteristics}

The substrate used in this study is peat-based ( $80 \%$ peat $+20 \%$ vermiculite $v / v)$. It is composed of $43.3 \%$ of large and medium fibers (between $0.850 \mathrm{~mm}$ and $2.00 \mathrm{~mm}$ ), $55.4 \%$ of short fibers (between $0.075 \mathrm{~mm}$ and $0.850 \mathrm{~mm})$, and $1.3 \%$ of fine particles $(<0.075 \mathrm{~mm})$, determined after drying substrate samples in the oven at $65^{\circ} \mathrm{C}$ and sieving using a Tylers ${ }^{\circledR}$ mechanical sieve (using fraction $<2 \mathrm{~mm}$ ). The substrate $\mathrm{pH}_{(\mathrm{H} 2 \mathrm{O})}$ is 3.80 and its cationic exchange capacity is $106.3 \mathrm{mEq} / 100 \mathrm{~g}$. The substrate's volumetric water content before watering was $0.08 \mathrm{~cm}^{3} \mathrm{~cm}^{-3}$, determined after drying three samples at $105^{\circ} \mathrm{C}$ for $24 \mathrm{~h}$.

\subsection{Assessment of the Quality and Physical Characteristics of Coated and Uncoated (Control) Fertilizers}

Three fertilizer samples were randomly selected (3 g per sample; 7 treatments: Aminaex, Biodrix N, Biodrix P, Biodrix $\mathrm{K}$, Urea, MAP, $\mathrm{KCl}$ ). The particles of each sample were spread on a Plexiglass plate and measured using WinSeedle ${ }^{\mathrm{TM}}$ software (Instruments Régent Inc., Quebec, QC, Canada). Several physical parameters were thus determined, namely projected area, straight length, curved length, diameter, volume, perimeter, and shape factor $(\mathrm{SF})\left[\mathrm{SF}=4 \pi^{*}\right.$ area $/$ (perimeter) $\left.{ }^{2}\right]$. The latter is a homogeneity indicator varying between 0 and 1 . The closer this coefficient is to 1 , the greater the fertilizer particle homogeneity.

\subsection{Release Kinetics of the Mineral Nutrients Contained in the Coated and Uncoated Fertilizers}

In the absence of substrate, four coated fertilizer samples (Aminaex, Biodrix N, Biodrix $\mathrm{P}$, and Biodrix K) were solubilized in a demineralized water solution at $0.1 \mathrm{~g}$ per $75 \mathrm{~mL}$ of deionized water in $120 \mathrm{ml}$ Erlenmeyer. Sulfuric acid $\left(\mathrm{H}_{2} \mathrm{SO}_{4}\right)$ was subsequently added to each sample at a concentration of $0.1 \mathrm{~g}$ per $75 \mathrm{~mL}$. After $24 \mathrm{~h}$ of mechanical stirring at a constant temperature of $25^{\circ} \mathrm{C}$, the following physicochemical parameters were measured: $\mathrm{pH}$ using a pH meter (Accumet $\mathrm{pH}$ meter 50, Fisher Scientific, Houston, TX, USA), electrical conductivity using a conductivity meter (model CDM83, Radiometer, Copenhagen, Denmark), and mineral nutrient concentration in each solubilized fertilizer [20]. The N$\mathrm{NO}_{3}$ and $\mathrm{N}-\mathrm{NH}_{4}$ concentrations were measured by colorimetry using a continuous flow spectrometer (model QuickChem 8000, Lachat Instruments, Milwaukee, WI, USA). The remaining elements, namely $\mathrm{P}, \mathrm{K}, \mathrm{Ca}$, and $\mathrm{Mg}$, were dosed using a plasma atomic emission spectrometer (ICAP 9000, Thermo Instruments, Franklin, MA, USA). The urea dosage was determined by liquid chromatography (model HPLC 1200 series, Agilent Technologies, Santa Clara, CA, USA).

The release kinetics of the mineral nutrients contained in the coated fertilizers were then assessed in the peat-based substrate $(80 \%$ peat $+20 \%$ vermiculite $v / v)$. Five treatments were studied (Urea, Biodrix N, MAP, Biodrix P, and a control without fertilizer) in completely randomized blocks using three repetitions per treatment (one repetition per block) and sampling date (8 dates). Each sample was placed in a $250 \mathrm{~mL}$ Erlenmeyer with peat substrate and demineralized water (peat and vermiculite:water 3:1, v/v). A homogenized mixture containing $46 \mathrm{~g}$ of peat substrate and $0.1 \mathrm{~g}$ of fertilizer (except for the control) were placed in each Erlenmeyer with $175 \mathrm{~mL}$ of demineralized water to maintain a relatively high volumetric water content (approximately $0.60 \mathrm{~cm}^{3} \mathrm{~cm}^{-3}$ ) throughout the 10-day experiment. The Erlenmeyer were sealed with parafilm to avoid evaporation water loss. Three Erlenmeyers per treatment and sampling date were collected after 1, 2, 3, 4, 7, 8, 9 , and 10 days. To determine the mineral nutrient concentration in each sample, the soil solution was extracted using the soil-saturation extract method. The substrate was first saturated with demineralized water, then the charged water was extracted by vacuum filtering [21]. Mineral nitrogen was determined by colorimetry using a continuous flow spectrophotometer (Quickchem $8000^{\circledR}$, Lachat Instruments, Milwaukee, WI, USA) while the other elements $(\mathrm{P}, \mathrm{K}, \mathrm{Ca}, \mathrm{Mg})$ were determined by plasma atomic emission spectrometry 
(model ICAP 9000, Thermo Instruments, Franklin, MA, USA). The pH and electrical conductivity (CE) were measured directly in the extracted solution $[20,22,23]$. The urea dosage was determined by liquid chromatography (model HPLC 1200 series, Agilent Technologies, Santa Clara, CA, USA).

\subsection{Mineral Nutrient Leaching with Coated and Uncoated Fertilizers in Two Growing Media}

The leaching experiment was carried out using perforated pots containing a volume of $600 \mathrm{~cm}^{3}$ (height of $9 \mathrm{~cm}$, diameter of $12.5 \mathrm{~cm}$ ). Two substrates were used: (i) S1, a mixture of peat and vermiculite $(3: 1, v / v)$; and (ii) S2, a mixture composed of $70 \%(v / v) \mathrm{S} 1+30 \%$ $(v / v)$ of Fafard BioSol compost (1.2-0.7-0.6). Both substrates were previously moistened to a volumetric water content of about $0.60 \mathrm{~cm}^{3} \mathrm{~cm}^{-3}$. For urea-based nitrogen fertilizers, eight treatments were tested: two substrates $(\mathrm{S} 1$ and S2) $\times$ four fertilizer treatments (control, Urea, Biodrix N, and Aminaex). For phosphate, three treatments (Biodrix P, MAP, and control) were tested in substrate S1 only ( $1 \mathrm{~g}$ per pot). The leaching of potassium was not evaluated because this element does not constitute a major pollutant either of the atmosphere or groundwater.

Pots were set up according to a completely random design, with four replicates per treatment. In each pot (except for controls), $10 \mathrm{~g}$ of fertilizer were spread in a single layer at about $2 / 3$ of the height of the pots filled with substrate. A $250 \mathrm{~cm}^{3}$ container was placed at the bottom of each pot to recover the leachate. The same amount of demineralized water (50-70 mL) was added to each pot at every sampling date to generate a leachate of about $40 \mathrm{~mL}$. Phosphorus was sampled on days 1,4, and 10, and nitrogen was sampled on days $1,4,5,7,15$, and 20. The leached soil solution was collected in $50 \mathrm{~mL}$ tubes two hours after irrigation. The electrical conductivity was immediately measured. The samples were then placed in the freezer at $-20{ }^{\circ} \mathrm{C} \mathrm{[24]} \mathrm{prior} \mathrm{to} \mathrm{measuring} \mathrm{the} \mathrm{mineral} \mathrm{nutrients} \mathrm{in} \mathrm{the}$ laboratory. The volumetric water content of the pots was measured by gravimetry and adjusted around $0.60 \mathrm{~cm}^{3} \mathrm{~cm}^{-3}$ during the experiment.

\subsection{Assessment of Nitrogen Protoxide $\left(\mathrm{N}_{2} \mathrm{O}\right)$ Emissions from Coated and Uncoated Fertilizers}

The experiment was carried out using the static closed-chamber method [25]. Four treatments were examined: Aminaex, Biodrix N, Urea, and a control without fertilizer. Substrate S2, consisting of $70 \%(v / v)$ of a mixture of peat and vermiculite $(3: 1, v / v)$ and $30 \%$ $(v / v)$ of Fafard BioSol compost (1.2-0.7-0.6) was used. Compost was added to this mixture to enhance microbial activity. Three replicates per treatment were used for a total of 12 pots as described by Marble et al. [26]. Plastic horticultural pots with a diameter of $15 \mathrm{~cm}$ and a volume of $1.33 \mathrm{~L}$ were used. The perforations at the base of each pot were sealed with insulating tape to prevent gases from escaping. For each treatment before potting, $10 \mathrm{~g}$ of fertilizer were mixed with the substrate to optimize denitrification conditions [26]. The mixture was then placed into pots and covered with $50 \mathrm{~g}$ of fertilizer-free S2 substrate. The volumetric water content was maintained at $0.60 \mathrm{~cm}^{3} \mathrm{~cm}^{-3}$ using the gravimetric method.

Polyvinyl chloride cylinders (PVC; diameter $=10.5 \mathrm{~cm}$ and height $=4.5 \mathrm{~cm}$ ) were placed $3 \mathrm{~cm}$ deep into the substrate $24 \mathrm{~h}$ before the start of the experiment and left in place for the duration of the study. Closed PVC chambers (diameter $=9.3 \mathrm{~cm}$ and height $=13.5 \mathrm{~cm}$ ) equipped with a rubber septum and a hole (to maintain atmospheric pressure without any significant gas loss) were placed on these cylinders at each sampling date to collect $\mathrm{N}_{2} \mathrm{O}$. Soil $\mathrm{CO}_{2}$ efflux was measured using a gas exchange system (LI-6400, equipped with a soil flux chamber, 6400-09; LI-COR Biosciences, Lincoln, NE, USA) at each sampling date one hour before the first $\mathrm{N}_{2} \mathrm{O}$ gas sampling.

$\mathrm{N}_{2} \mathrm{O}$ emissions were measured on days $1,3,5,7,10,13,15$, and 20 by manually collecting $10 \mathrm{~mL}$ air samples at $0,2.5,5$, and $7.5 \mathrm{~h}$ using a highly gas-tight hypodermic syringe (10 mL, Becton-Dickinson 309643, Franklin Lakes, NJ, USA) through the septum. The samples were immediately transferred to $11.1 \mathrm{~mL}$ glass vials (Agilent, $20 \mathrm{~mm}, 5$ 18220388). The vials were pre-evacuated to minimize atmospheric gas concentration [27]. The evacuation was carried out using a vacuum pump (CRB Cat. Betsy, QC, Canada) connected 
to a helium pressure vessel (5.0 Ultra High Purity, Praxair, QC, Canada). Gases contained in the vials were sucked three times at $-100 \mathrm{kPa}$, and helium was injected after every other evacuation. After the last evacuation, the vials were tightly closed with $2-\mathrm{W}-\mathrm{C}$ septa (Helvoet-Pharma Wheaton cat. 224 100-194, Milleville, NJ, USA), specifically selected for $\mathrm{N}_{2} \mathrm{O}$ [27] and aluminum joints (20 mm, 224178-01, Wheaton, Milleville, NJ, USA). 2008). The controls were prepared using the same procedure $[25,28]$.

Gas samples were analyzed within seven days of sampling using a gas chromatograph (model $6890 \mathrm{~N}$ Agilent, Wilmington, DE, USA) equipped with an electron capture detector with a 30 m HP-PLOT-Q column (19095P-QO4PT) and a Combi-Pal autosampler. Helium (UH-T 5.0, Praxair, Darbury, CT, USA) was used as carrier gas. $\mathrm{N}_{2} \mathrm{O}$ fluxes $\left(\mathrm{F}_{\mathrm{N} 2 \mathrm{O}}, \mu \mathrm{g}\right.$ $\mathrm{N}_{2} \mathrm{O} \mathrm{m} \mathrm{m}^{-2} \mathrm{~h}^{-1}$ ) were calculated using a flux model for variable gas concentrations in the chamber [25], with the following formula:

$$
\mathrm{F}_{\mathrm{N} 2 \mathrm{O}}=\mathrm{b} \times\left(\mathrm{V}_{\mathrm{CH}} / \mathrm{A}_{\mathrm{CH}}\right) \times\left[\left(1-\left(\mathrm{e}_{\mathrm{p}} / \mathrm{P}\right)\right]\right.
$$

where $\mathrm{b}$ is the concentration increase $\left(\mu \mathrm{g} \mathrm{N} \mathrm{N}_{2} \mathrm{O} \mathrm{ml}^{-1} \mathrm{~h}^{-1}\right) ; \mathrm{V}_{\mathrm{CH}}$ is the volume of the measuring chamber $\left(\mathrm{cm}^{3}\right) ; \mathrm{A}_{\mathrm{CH}}$ is the surface of the base of the measuring chamber $\left(\mathrm{m}^{2}\right), \mathrm{e}_{\mathrm{p}}$ is the partial pressure of water vapor in the chamber $(\mathrm{kPa})$, and $\mathrm{P}$ is atmospheric pressure $(\mathrm{kPa})$. The partial pressure of water vapor determined with the LI-6400 during soil respiration $\left(\mathrm{CO}_{2}\right)$ measurements was used as the $\mathrm{e}_{\mathrm{p}}$ value at time $0\left(\mathrm{t}_{0}\right)$.

\subsection{Statistical Analyses}

The physical quality of coated and uncoated fertilizers was compared using Student's $t$-test for mean comparisons [29]. For nitrogen, variance analysis was performed followed by Tukey's multiple comparisons test. The assumptions of residue normality and variance uniformity for the different variables measured were verified using the UNIVARIATE

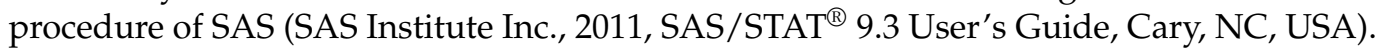
The threshold of statistical significance was set at $p \leq 0.05$ for all analyses.

Regression using the SAS REG procedure was used to assess the release kinetics of mineral nutrients as a function of time and treatment and their interaction, as well as to evaluate the quantity of phosphorus leached overtime per treatment. The regression function parameters were then compared using a PROC GLM procedure. A repeatedmeasures ANOVA with the PROC MIXED procedure was used to compare mean mineral nutrient quantities leached for each sampling date. The same approach was used to assess the effects of treatment on $\mathrm{pH}$ and the electrical conductivity of the substrate.

To compare the $\mathrm{N}_{2} \mathrm{O}$ emissions and nitrogen leached between the coated and uncoated fertilizers at each sampling date, a repeated-measures ANOVA was performed. Cumulative $\mathrm{N}_{2} \mathrm{O}$ efflux estimates were calculated by integration over time using the trapezoidal rule [26]. For unsampled days, linear interpolation was performed [30] after having confirmed the linear increase of efflux for at least $24 \mathrm{~h}$ during preliminary tests. On day 20, the cumulative fluxes and accumulated nitrogen were compared using the PROC MIXED procedure with Tukey's means comparisons test.

\section{Results}

\subsection{Physical Characteristics of Fertilizer Particles}

For nitrogen fertilizers, the difference was not significant between Urea, Aminaex, and Biodrix $\mathrm{N}$ for all physical parameters measured except the shape factor. For the latter, a significant difference $(p<0.0001)$ was observed between the three nitrogen fertilizers Biodrix N, Aminaex, and Urea (Table 1). The shape factor of uncoated Urea particles was 0.96 , which is slightly higher than that of the other two fertilizers and closer to 1 , indicating slightly greater homogeneity in Urea particles. Significant differences were observed between phosphate and potassium fertilizers (coated and uncoated) for both mineral nutrients ( $\mathrm{P}$ and $\mathrm{K}$ ) for all physical parameters analyzed (Table 1 ). The shape factor of $\mathrm{KCl}$ and Biodrix $\mathrm{K}$ was 0.87 and 0.86 , respectively, similar to those of Biodrix $\mathrm{P}$ and MAP (0.89 and 0.93 , respectively). 
Table 1. Physical characteristics of coated (Aminaex and Biodrix N) and uncoated (Urea) nitrogenous fertilizers, potassium fertilizers (Biodrix K vs. KCl), and phosphate fertilizers (Biodrix P vs. MAP).

\begin{tabular}{|c|c|c|c|c|c|c|c|}
\hline \multirow{3}{*}{ Physical Characteristics } & \multicolumn{7}{|c|}{ Fertilizers } \\
\hline & \multicolumn{3}{|c|}{ Nitrogen } & \multicolumn{2}{|c|}{ Potassium } & \multicolumn{2}{|c|}{ Phosphorus } \\
\hline & Aminaex & Biodrix N & Urea & Biodrix K & $\mathrm{KCl}$ & Biodrix $P$ & MAP \\
\hline Shape factor & $0.94 \pm 0.04 \mathrm{~b}$ & $0.94 \pm 0.04 b$ & $0.96 \pm 0.05 \mathrm{a}$ & $0.86 \pm 0.06 \mathrm{~b}$ & $0.87 \pm 0.06 \mathrm{a}$ & $0.89 \pm 0.06 \mathrm{a}$ & $0.93 \pm 0.07 b$ \\
\hline Projected area $\left(\mathrm{mm}^{2}\right)$ & $7.00 \pm 1.51 \mathrm{a}$ & $6.83 \pm 2.15 a$ & $6.83 \pm 2.51 \mathrm{a}$ & $10.58 \pm 3.49 \mathrm{~b}$ & $8.98 \pm 3.09 a$ & $10.45 \pm 3.28 \mathrm{a}$ & $4.93 \pm 2.26 b$ \\
\hline Straight length (mm) & $3.26 \pm 0.45 \mathrm{a}$ & $3.19 \pm 0.55 \mathrm{a}$ & $3.15 \pm 0.61 \mathrm{a}$ & $4.33 \pm 0.80 \mathrm{~b}$ & $3.97 \pm 0.73 \mathrm{a}$ & $4.10 \pm 0.73 \mathrm{a}$ & $2.75 \pm 0.65 b$ \\
\hline Curved length (mm) & $3.37 \pm 0.47 \mathrm{a}$ & $3.32 \pm 0.57 \mathrm{a}$ & $3.36 \pm 0.61 \mathrm{a}$ & $4.57 \pm 0.81 b$ & $4.28 \pm 0.75 \mathrm{a}$ & $4.33 \pm 0.78 \mathrm{a}$ & $3.04 \pm 0.66 b$ \\
\hline Circular volume $\left(\mathrm{mm}^{3}\right)$ & $13.49 \pm 4.19 \mathrm{a}$ & $13.45 \pm 6.46 \mathrm{a}$ & $14.37 \pm 7.71 \mathrm{a}$ & $24.31 \pm 12.24 b$ & $20.30 \pm 11.04 \mathrm{a}$ & $25.33 \pm 12.46 \mathrm{a}$ & $9.26 \pm 6.41 b$ \\
\hline Cercle area $\left(\mathrm{mm}^{2}\right)$ & $22.81 \pm 4.93 \mathrm{a}$ & $22.47 \pm 6.93 \mathrm{a}$ & $23.40 \pm 8.21 \mathrm{a}$ & $34.93 \pm 11.21 \mathrm{~b}$ & $30.97 \pm 10.50 \mathrm{a}$ & $34.92 \pm 11.17 \mathrm{a}$ & $17.63 \pm 7.66 \mathrm{~b}$ \\
\hline Ellipsoidal area $\left(\mathrm{mm}^{2}\right)$ & $16.62 \pm 3.60 \mathrm{a}$ & $16.38 \pm 5.05 \mathrm{a}$ & $17.05 \pm 5.98 \mathrm{a}$ & $25.46 \pm 8.17 \mathrm{~b}$ & $22.57 \pm 7.65 \mathrm{a}$ & $25.45 \pm 8.14 \mathrm{a}$ & $12.85 \pm 5.58 \mathrm{~b}$ \\
\hline Projected perimeter $(\mathrm{mm})$ & $9.62 \pm 1.12 \mathrm{a}$ & $9.45 \pm 1.53 \mathrm{a}$ & $9.30 \pm 1.77 \mathrm{a}$ & $12.33 \pm 2.06 \mathrm{~b}$ & $11.26 \pm 1.92 \mathrm{a}$ & $12.07 \pm 2.02 \mathrm{a}$ & $7.99 \pm 1.90 \mathrm{~b}$ \\
\hline
\end{tabular}

Nitrogen fertilizers: Mean $(\mathrm{n}=9) \pm$ standard deviation. The average number of particles per sample was slightly variable among the 3 samples: Aminaex $(n=211-222)$, Biodrix N $(n=201-241)$, Urea $(n=198-216)$. For each of the physical characteristics, the same letter indicates a non-significant difference between the three fertilizers according to a Tukey test at $\alpha=0.05$. Potassium and phosphorus fertilizers: Mean $(n=6) \pm$ standard deviation. The average number of particles per sample (3 samples) was: Biodrix K ( $=97-98)$, Biodrix $\mathrm{P}(\mathrm{n}=83-104), \mathrm{MAP}(\mathrm{n}=228-289)$ and $\mathrm{KCl}(\mathrm{n}=124-128)$. For each of the physical characteristics, the same letter indicates a non-significant difference between the two types of fertilizer (conventional vs. coated: KCl vs. Biodrix K; MAP vs. Biodrix P) according to a Student's $t$-test at $\alpha=0.05$.

\subsection{Release Kinetics of Coated and Uncoated Fertilizers}

After $24 \mathrm{~h}$ in deionized water $\left(25^{\circ} \mathrm{C}\right), 98 \%$ and $97 \%$ of urea were released by Biodrix $\mathrm{N}$ and Aminaex, respectively, while $45.5 \%$ of $\mathrm{P}_{2} \mathrm{O}_{5}$ was released by Biodrix P. Based on initial mineral nutrient concentrations contained in the fertilizers, the solubilization of coated fertilizers was complete after $24 \mathrm{~h}$ (Table 2). When nitrogen fertilizers were incorporated into a peat-based substrate, the release of urea and N-urea by Biodrix $\mathrm{N}$ and Urea followed the same release kinetics for both forms of nitrogen (Figure 1). The regression curves for coated nitrogen (Biodrix N) and the standard uncoated fertilizer (Urea) did not differ significantly. As expected, there was no release in the control treatment because the peat substrate did not contain nitrogen (Figure 1). A significant difference was observed between Urea and Biodrix $\mathrm{N}$ two hours after the beginning of the experiment (repeated measures ANOVA, $p<0.0001$ ). At that time, Biodrix $\mathrm{N}$ released $34 \%$ less and $\mathrm{N}$-urea than Urea (Figure 2). In this relatively wet substrate, the difference disappeared after day one and no significant difference was observed thereafter in regard to the release kinetics of the two fertilizers $(p=0.5829)$. For mineral nitrogen $\left(\mathrm{NH}_{4}\right.$ and $\left.\mathrm{NO}_{3}\right)$, there was no significant difference between the two fertilizers $(p=0.3505)$. Based on the regression analysis, the mineral nitrogen concentration of the substrate varied linearly with time for Biodrix $\mathrm{N}$ and Urea treatments (Figure 3). The release kinetics of phosphorus with Biodrix P and MAP were also similarly based on a quadratic model (Figure 4). However, no significant difference $(p=0.3824)$ was observed between these two fertilizers during the 10-day period of the study.

The release of nitrogen by Biodrix $\mathrm{N}$ and Urea led to a significant increase $(p<0.0001)$ in $\mathrm{pH}$ and electrical conductivity (EC) of the peat substrate when compared with the control $\left(\mathrm{pH}_{(\mathrm{H} 2 \mathrm{O})}\right.$ of 5.0 vs. 4.3 ; $\mathrm{EC}$ of 100 vs. $80 \mu \mathrm{Sm}^{-1}$, respectively; Figure 5). In addition, the change in $\mathrm{pH}$ and electrical conductivity in the substrate followed a similar trend throughout the study with both fertilizers (Urea and Biodrix $\mathrm{N}$ ). The $\mathrm{pH}_{(\mathrm{H} 2 \mathrm{O})}$ increased from 5.0 to 5.7 (repeated measures ANOVA, $p=0.0549$ ) and the EC from $100 \mu \mathrm{S} \mathrm{cm}^{-1}$ to $240 \mu \mathrm{S} \mathrm{cm}^{-1}(p=0.0964)$ (Figure 5). In contrast to nitrogen, phosphorus significantly decreased $\mathrm{pH}\left(\mathrm{pH}_{(\mathrm{H} 2 \mathrm{O})}\right.$ in regards to the control from 4.35 to 4.10; Figure 6). However, the electrical conductivity of the substrate was four times higher in Biodrix P and MAP than in the control treatment (mean EC of 325 vs. $80 \mu \mathrm{S} \mathrm{cm}^{-1}$ ). Repeated measurements showed that Biodrix P and MAP had a similar effect on $\mathrm{pH}(p=0.3334)$ and electrical conductivity $(p=0.4247)$ of the peat-based substrate throughout the experiment (Figure 6). 

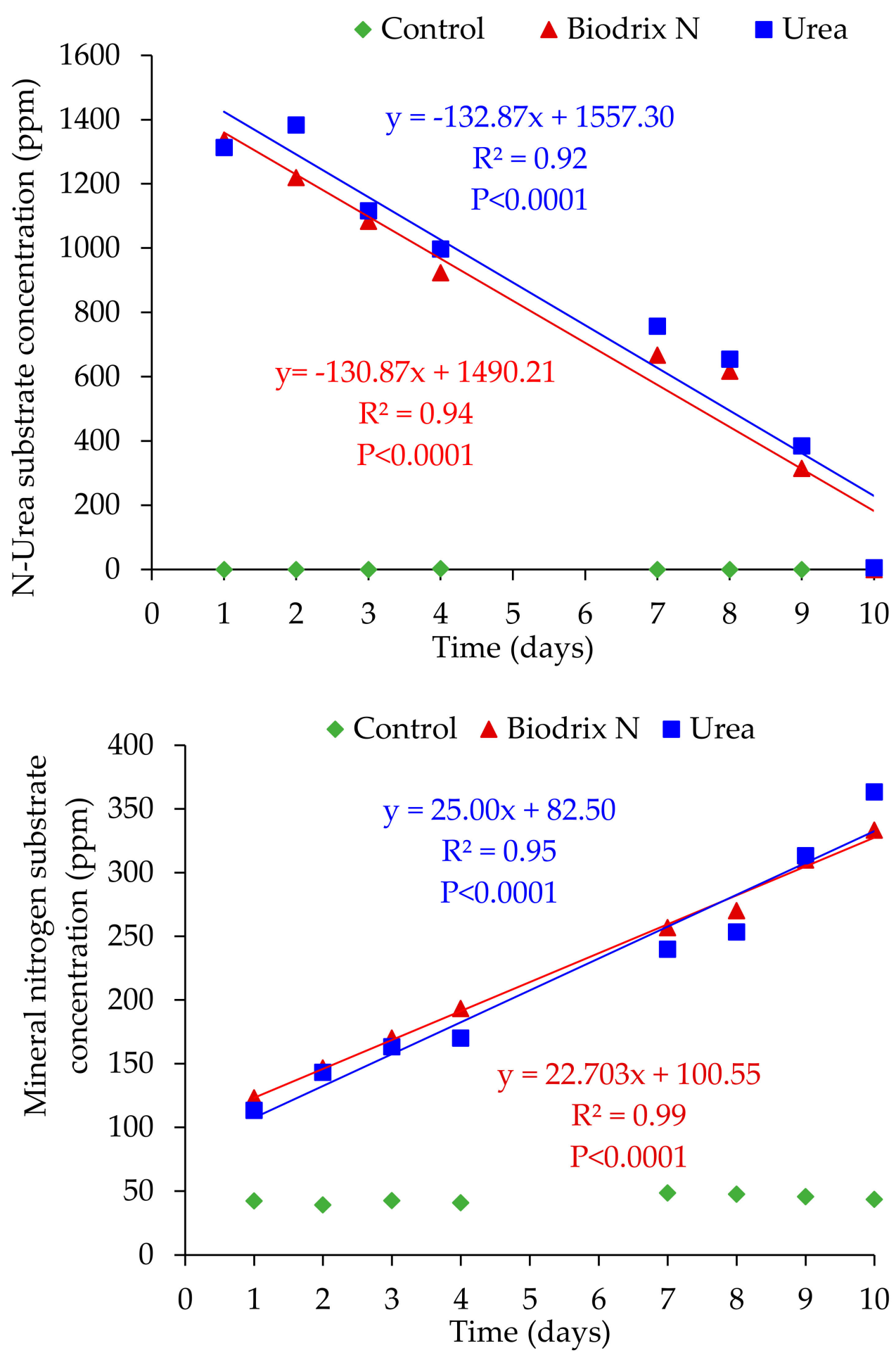

Figure 1. Relationships between (i) N-urea and (ii) mineral nitrogen substrate concentrations and time (days) for Biodrix N, Urea, and control. 


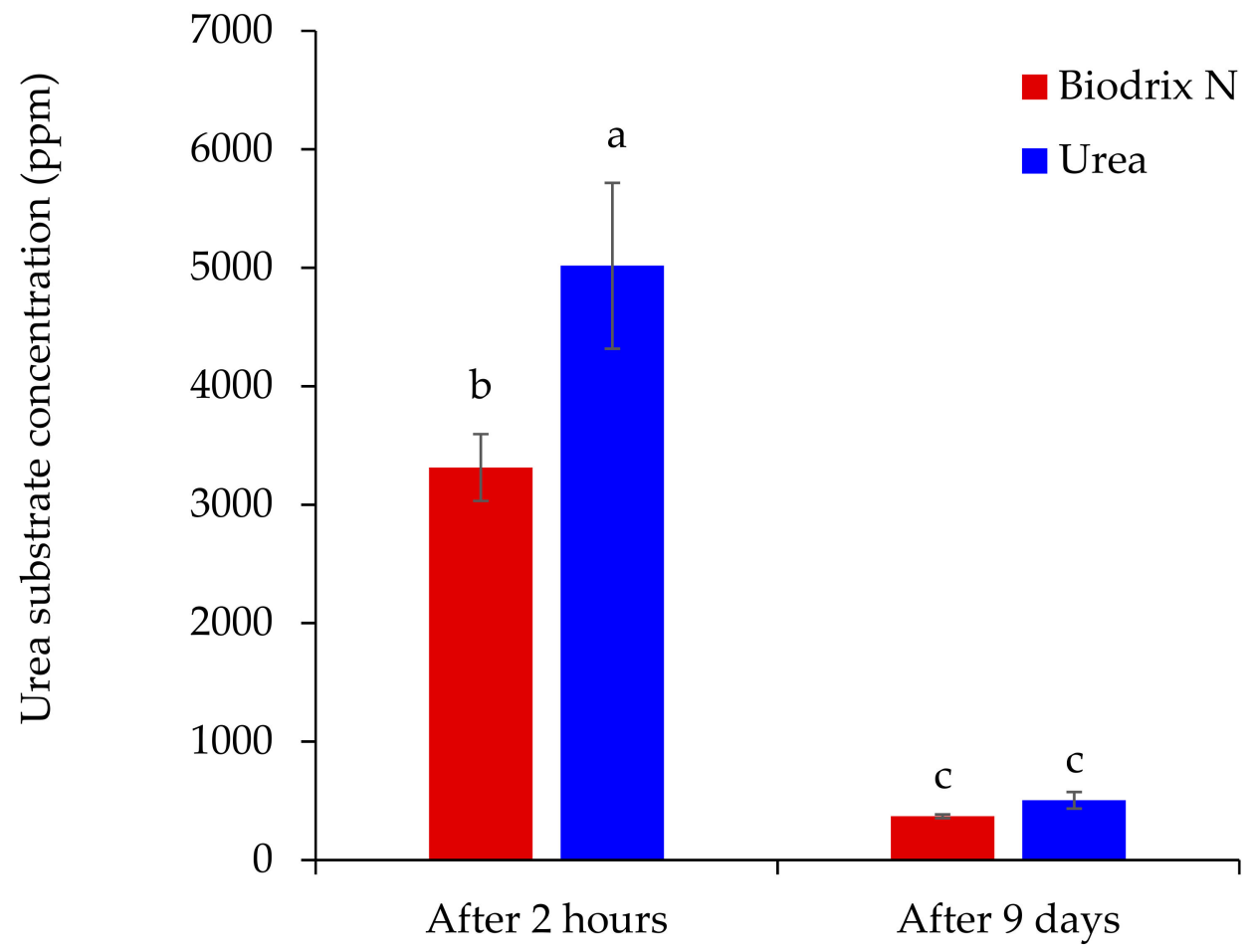

Figure 2. Urea substrate concentrations (mean \pm standard error; $n=3$ ) for the two treatments Biodrix $\mathrm{N}$ and Urea after $2 \mathrm{~h}$ and 9 days. The same letter indicates non-significant differences between treatments according to a Tukey's test at $\alpha=0.05$.

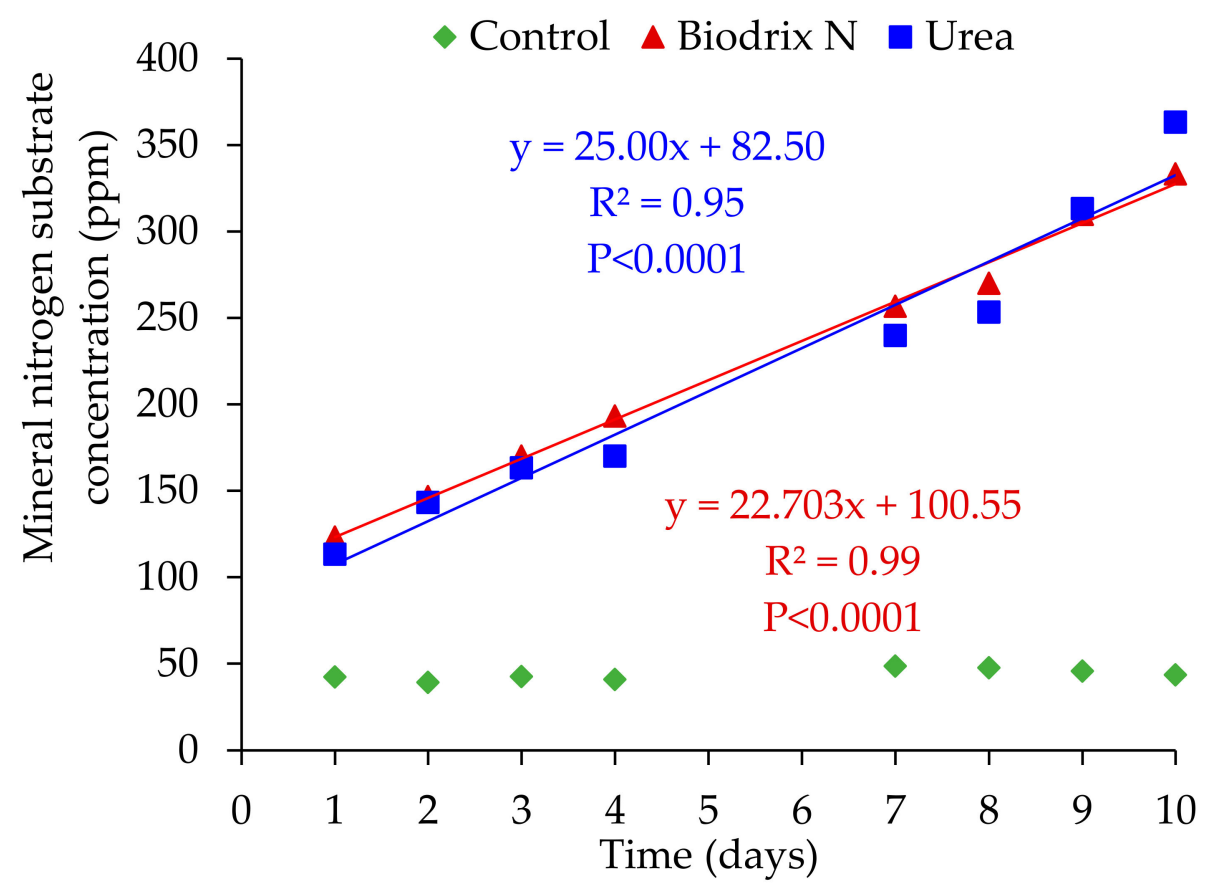

Figure 3. Relationships between mineral nitrogen substrate concentration and time (days) for Biodrix $\mathrm{N}$, Urea, and control. 


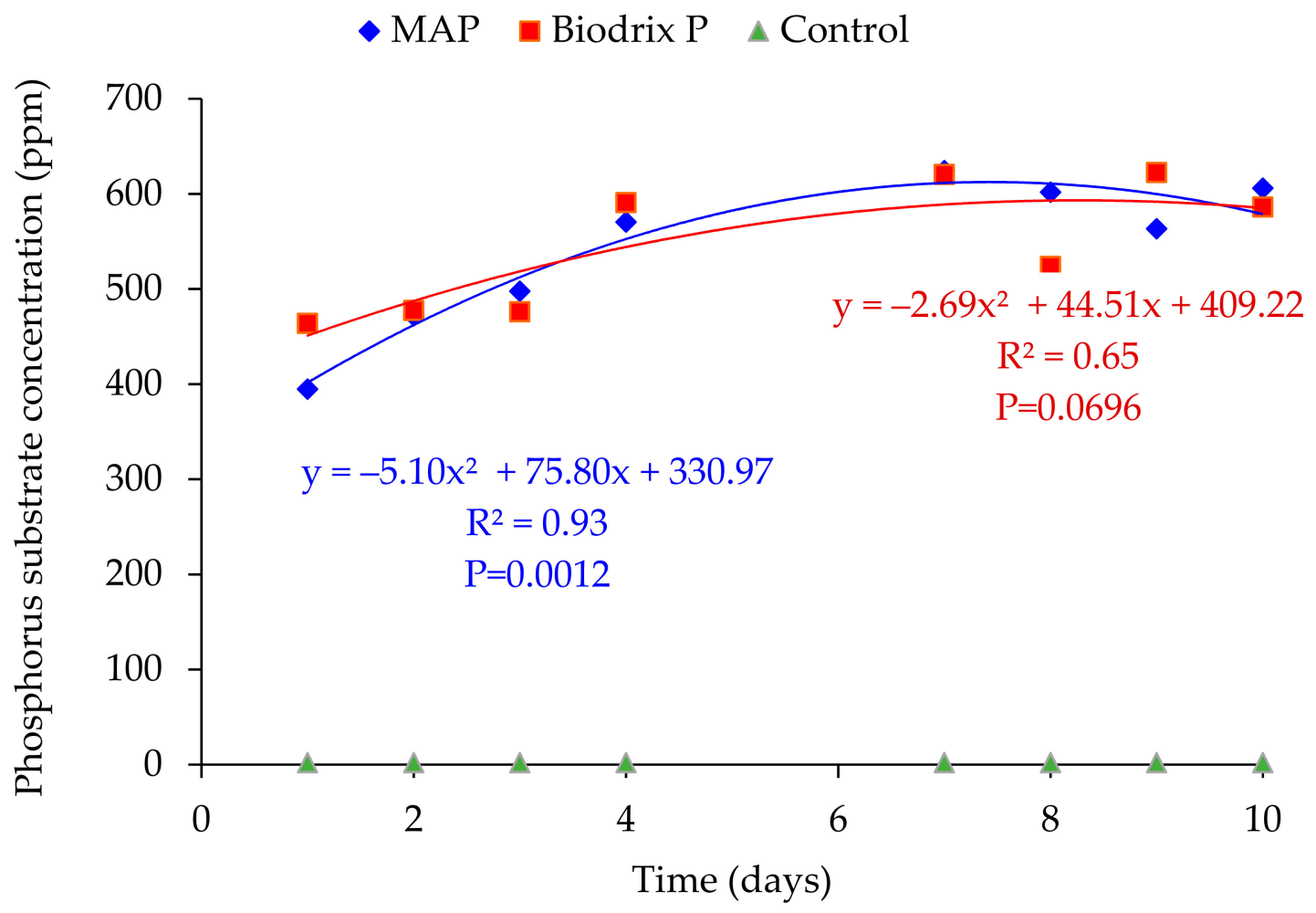

Figure 4. Relationships between phosphorus substrate concentration and time (days) for Biodrix P, MAP, and control.

Table 2. Percentage of mineral nutrients contained in coated fertilizers released after $24 \mathrm{~h}$ in demineralized water.

\begin{tabular}{|c|c|c|c|c|}
\hline \multirow{2}{*}{ Mineral Nutrients } & \multicolumn{4}{|c|}{ Fertilizer } \\
\hline & Aminaex & Biodrix $\mathbf{N}$ & Biodrix $P$ & Biodrix K \\
\hline $\mathrm{N}-\mathrm{NH}_{4}(\%)$ & 0.04 & 0.04 & 10.40 & 0.17 \\
\hline $\mathrm{N}-\mathrm{NO}_{3}(\%)$ & 0.01 & 0.01 & 0.01 & 0.10 \\
\hline $\mathrm{P}(\%)$ & 0.01 & 0.01 & $20.30 \pm 0.07$ & $0.02 \pm 0.29$ \\
\hline $\mathrm{K}(\%)$ & $0.04 \pm 0.29$ & $0.05 \pm 0.08$ & $0.10 \pm 0.16$ & $40.70 \pm 0.09$ \\
\hline $\mathrm{Ca}(\%)$ & $0.71 \pm 0.12$ & $1.25 \pm 0.10$ & $1.84 \pm 0.17$ & $1.25 \pm 0.32$ \\
\hline $\operatorname{Mg}(\%)$ & $0.30 \pm 0.13$ & $0.10 \pm 0.10$ & $0.20 \pm 0.35$ & $0.30 \pm 0.27$ \\
\hline $\mathrm{Cl}(\%)$ & $0.03 \pm 0.17$ & 0.04 & $0.06 \pm 0.37$ & $44.70 \pm 0.05$ \\
\hline $\mathrm{NO}_{3}(\%)$ & 0.02 & 0.02 & $0.03 \pm 0.57$ & $0.25 \pm 0.09$ \\
\hline $\mathrm{SO}_{4}(\%)$ & $0.02 \pm 0.25$ & $0.03 \pm 0.22$ & $8.01 \pm 0.07$ & $0.08 \pm 0.25$ \\
\hline $\mathrm{HPO}_{4}(\%)$ & - & - & $57.40 \pm 0.02$ & $0.11 \pm 1.20$ \\
\hline Urea (\%) & $97.00 \pm 0.02$ & $98.00 \pm 0.04$ & - & - \\
\hline
\end{tabular}

Mean $(\mathrm{n}=4) \pm$ standard deviation. This solubilization test aimed to verify the initial concentrations of mineral nutrients in each coated fertilizer. The release kinetics of these fertilizers were evaluated during leaching tests.

\subsection{Mineral Nutrient Leaching by Coated and Conventional Fertilizers}

Nitrogen leaching in substrate S1, which contained no compost, revealed that the leached quantities of $\mathrm{N}^{-\mathrm{NO}_{3}}$ over 20 days were very low and negligible $(<1 \mathrm{mg})$. Conversely, the amount of $\mathrm{N}-\mathrm{NH}_{4}$ in leached solutions was moderately high, reaching a maximum value of about $53 \mathrm{mg}$ on day 4 with the Urea treatment. A delay in mineral nitrogen leaching was observed with the Aminaex and Biodrix $\mathrm{N}$ treatments. Indeed, after fertilizer applications, the quantity of mineral nitrogen found in the form of ammonium was significantly lower than that observed with Urea on days 4 and $5(p<0.0001$; Figure 7$)$. Maximum leaching for Aminaex and Biodrix $\mathrm{N}$ was observed on day 7 with ammonium nitrogen levels $48 \%$ and $20 \%$ lower than Urea, respectively. After 20 days, Aminaex significantly reduced cumulative nitrogen leaching in the form of ammonium ( $p=0.0277)$ by $40 \%$ 
compared to Urea, whereas a non-significant reduction of $26 \%$ was observed in Biodrix $\mathrm{N}$ compared to Urea $(p=0.1469)$.
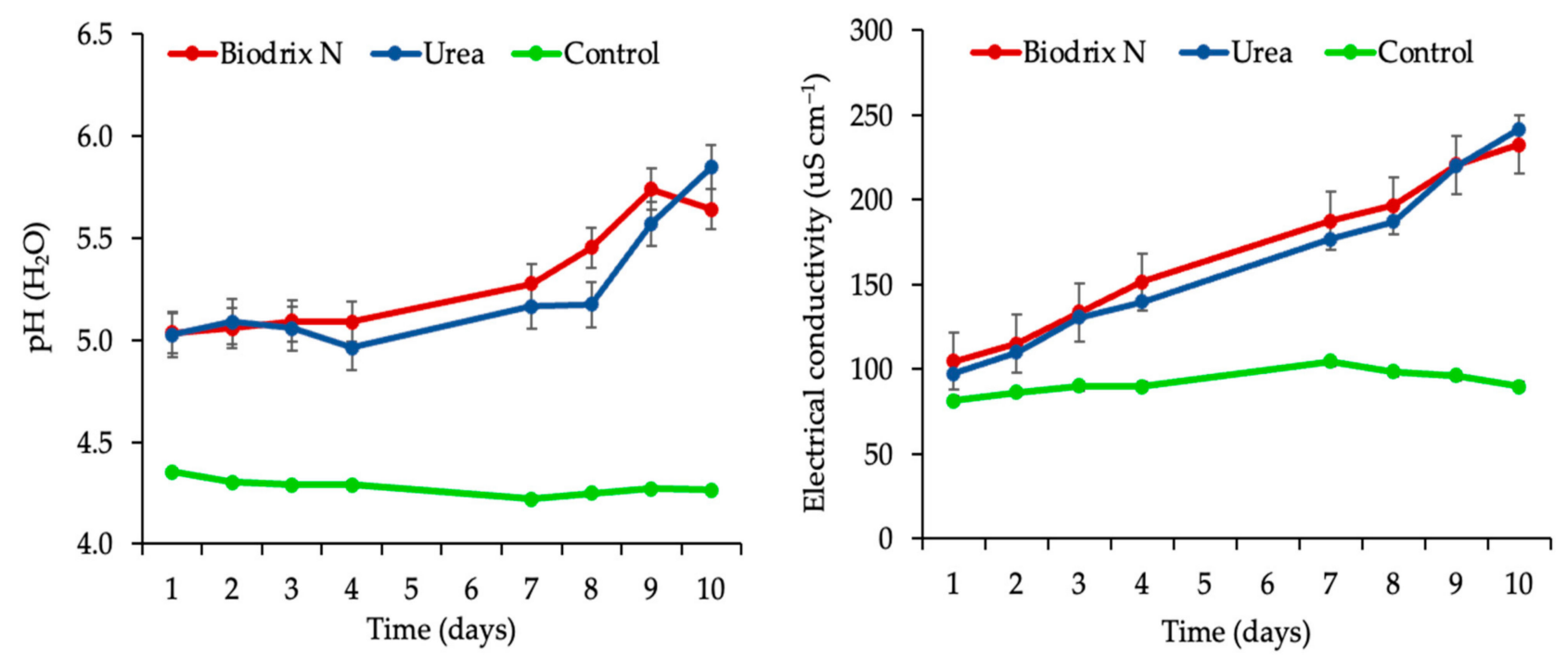

Figure 5. Effect of nitrogen fertilizers (Urea, Biodrix $\mathrm{N}$ ) on the $\mathrm{pH}_{(\mathrm{H} 2 \mathrm{O})}$ and the electrical conductivity of the substrate. Error bars represent standard errors.
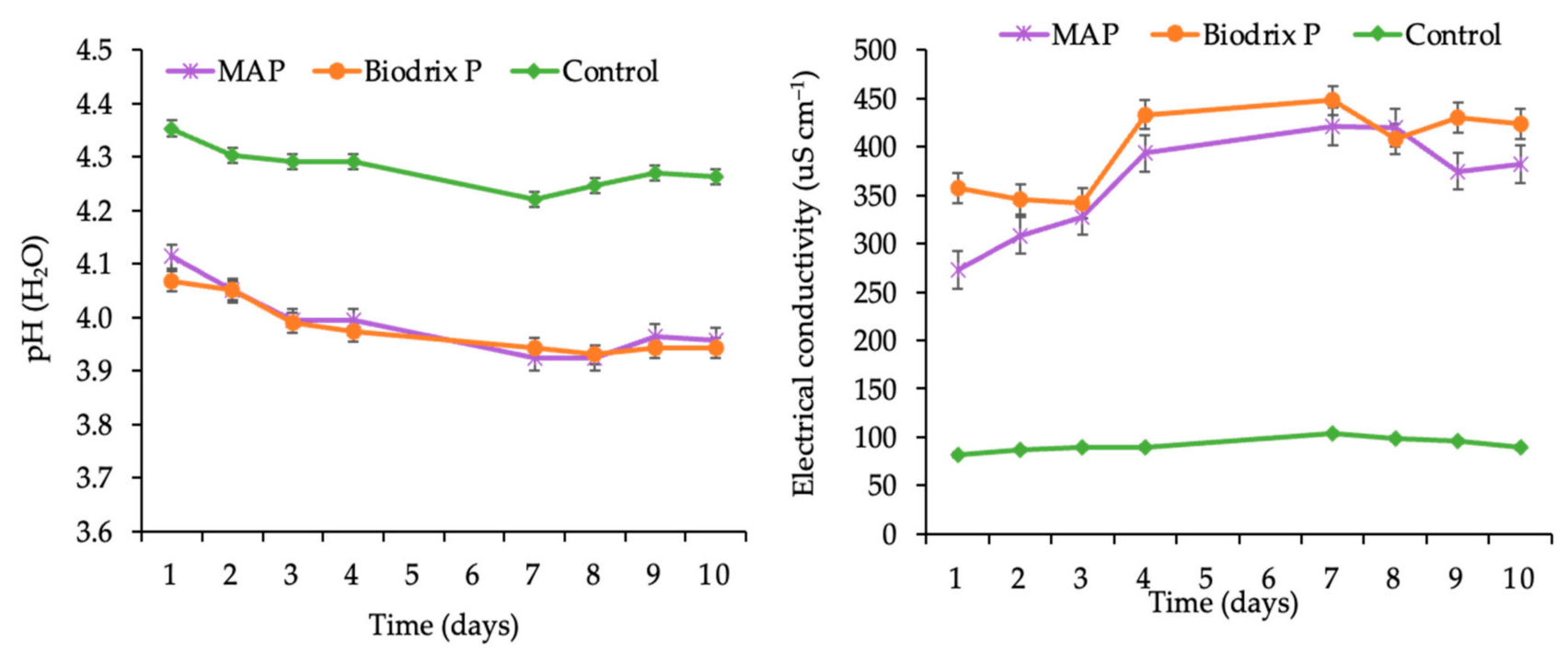

Figure 6. Effect of phosphate fertilizers (MAP, Biodrix $\mathrm{P}$, and Control) on the $\mathrm{pH}_{(\mathrm{H} 2 \mathrm{O})}$ and the electrical conductivity of the substrate. Error bars represent standard errors.

In substrate S2, where compost was added to stimulate microbial activity, the amount of $\mathrm{N}-\mathrm{NH}_{4}$ in leached solutions increased continuously in the Urea treatment (Figure 8). On the first sampling day, the amount of $\mathrm{N}^{-\mathrm{NH}_{4}}$ was significantly lower $(p<0.0001)$ with Urea than Biodrix $\mathrm{N}$ and Aminaex. The latter reached maximum N-NH $\mathrm{N}_{4}$ leaching values on days 4 and 5, respectively, followed by a gradual decrease. Along with this decrease, significantly higher amounts of $\mathrm{N}-\mathrm{NH}_{4}$ were observed on days 15 and 20 for Urea. On the other hand, there was no significant difference in terms of cumulative $\mathrm{N}-\mathrm{NH}_{4}$ losses after 20 days for all three treatments ( $p=0.2038$; Table 3 ). The quantity of $\mathrm{N}-\mathrm{NO}_{3}$ in the leached solutions of the Urea treatment was high during the first days, reaching a maximum on day 4. In addition, the difference in leached nitrates between Urea and the two other treatments (Aminaex and Biodrix $\mathrm{N}$ ) was significant at each sampling day $(p<0.0001)$. For these last two treatments, the leaching of $\mathrm{N}-\mathrm{NO}_{3}$ increased after day 5 . However, the cumulative 
quantity of nitrates leached after 20 days with the Urea treatment was significantly higher than those leached by Aminaex ( $p=0.0026)$ and Biodrix N $(p=0.0004)$, with $41 \%$ and $54 \%$, respectively (Table 3).
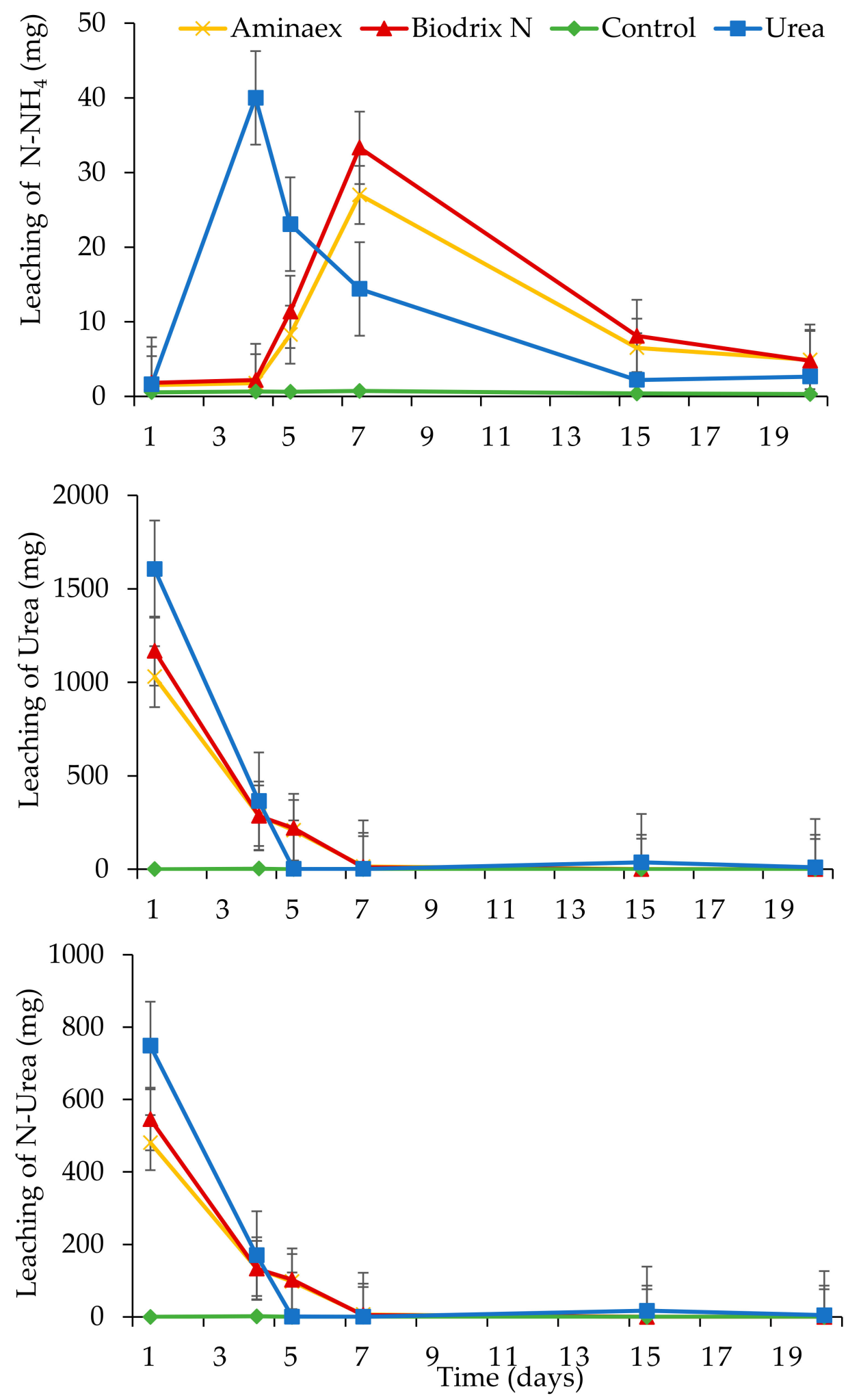

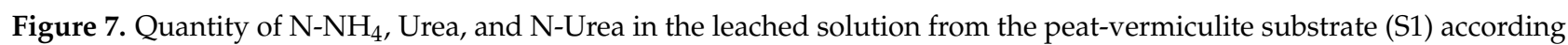
to the treatment and time (days). Error bars represent standard errors. 

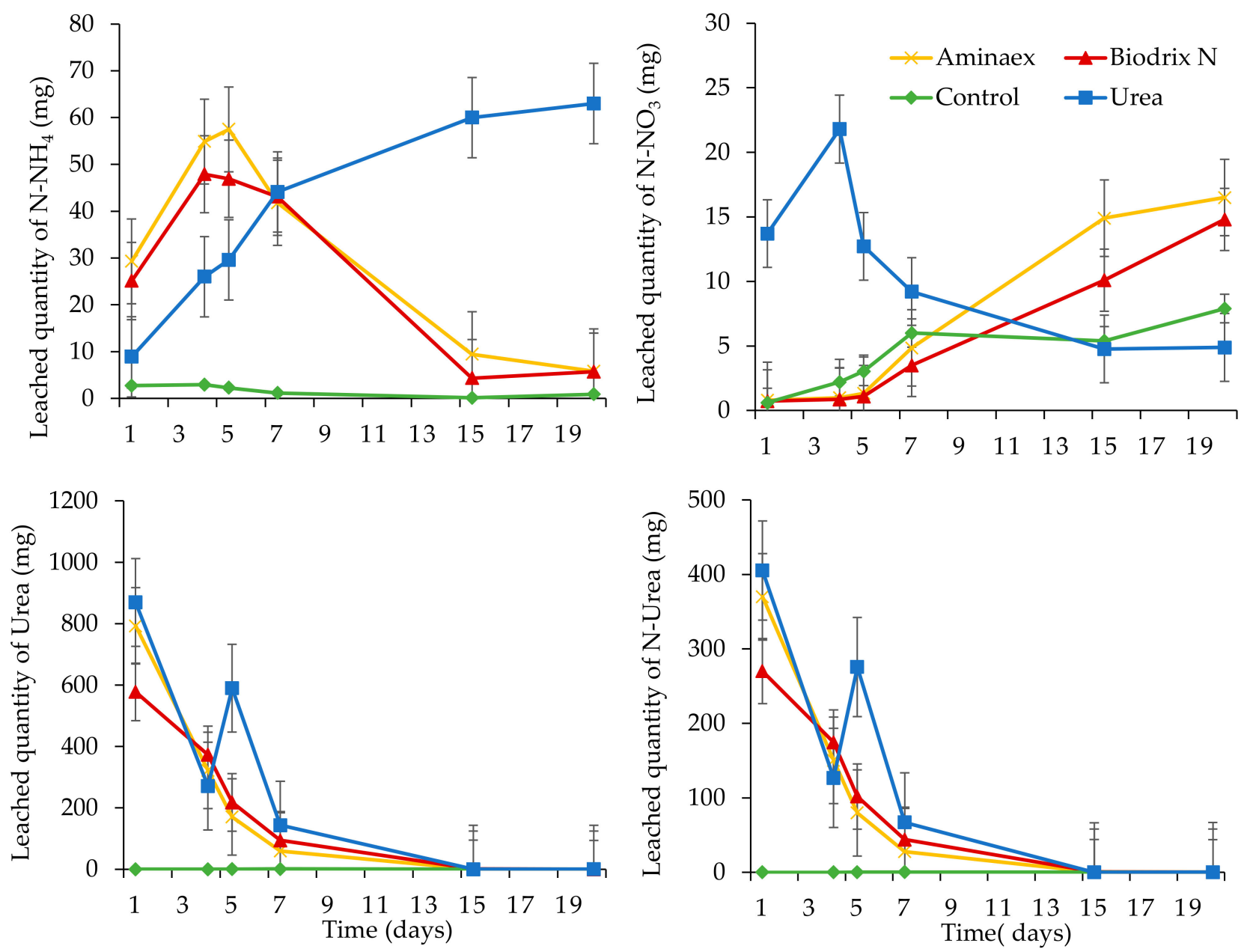

Figure 8. Quantity of $\mathrm{N}-\mathrm{NH}_{4}, \mathrm{~N}-\mathrm{NO}_{3}$, Urea, and N-Urea in the leached solution from the peat-vermiculite-compost substrate (S2) according to the treatment and time (days). Error bars represent standard errors.

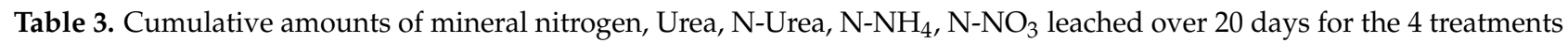
(Aminaex, Biodrix N, Urea, and Control) in substrates S1 and S2.

\begin{tabular}{|c|c|c|c|c|c|}
\hline & & Aminaex & Biodrix $\mathbf{N}$ & Urea & Control \\
\hline \multirow{3}{*}{ Substrate S1 } & Cumul. Urea (mg) & $1540.44 \pm 0.20 \mathrm{a}$ & $1683.96 \pm 0.09 \mathrm{a}$ & $2019.11 \pm 0.25 \mathrm{a}$ & $4.80 \pm 1.07 \mathrm{~b}$ \\
\hline & Cumul. N-Urea (mg) & $719.45 \pm 0.20 \mathrm{a}$ & $787.45 \pm 0.09 \mathrm{a}$ & $942.31 \pm 0.25 \mathrm{a}$ & $2.24 \pm 1.07 b$ \\
\hline & $\begin{array}{l}\text { Cumul. mineral } \\
\text { nitrogen (mg) }\end{array}$ & $50.29 \pm 0.40 b$ & $61.82 \pm 0.20 \mathrm{ab}$ & $84.08 \pm 0.13 \mathrm{a}$ & $3.37 \pm 0.24 \mathrm{c}$ \\
\hline \multirow{5}{*}{ Substrate S2 } & Cumul. Urea (mg) & $1345.21 \pm 0.10 \mathrm{~b}$ & $1263.72 \pm 0.15 b$ & $1874.19 \pm 0.13 \mathrm{a}$ & $1.29 \pm 0.85 c$ \\
\hline & Cumul. N-Urea (mg) & $627.79 \pm 0.10 \mathrm{~b}$ & $590.42 \pm 0.15 b$ & $874.65 \pm 0.13 \mathrm{a}$ & $0.60 \pm 0.85 c$ \\
\hline & Cumul. N-NH 4 (mg) & $198.74 \pm 0.30 \mathrm{a}$ & $173.05 \pm 0.16 \mathrm{a}$ & $231.60 \pm 0.07 \mathrm{a}$ & $10.03 \pm 0.08 \mathrm{~b}$ \\
\hline & Cumul. N-NO ${ }_{3}(\mathrm{mg})$ & $39.36 \pm 0.26 \mathrm{~b}$ & $31.08 \pm 0.14 b$ & $67.08 \pm 0.13 \mathrm{a}$ & $25.16 \pm 0.10 \mathrm{~b}$ \\
\hline & $\begin{array}{l}\text { Cumul. mineral } \\
\text { nitrogen (mg) }\end{array}$ & $238.80 \pm 0.24 \mathrm{ab}$ & $202.60 \pm 0.13 b$ & $297.32 \pm 0.06 \mathrm{a}$ & $35.22 \pm 0.10 \mathrm{c}$ \\
\hline
\end{tabular}

Means ( \pm standard deviation) were separated using Tukey's least significant difference test $(\alpha=0.05)$. The same letter indicates nonsignificant differences among treatments. Total volumes of leached water over the six samplings (days 1, 4, 5, 7, 15, and 20) were approximately $250 \mathrm{~mL}$ in each of the treatments. The quantity observed in the S2 substrate control indicates the nitrogen provided by the compost. 


\section{4. $\mathrm{N}_{2} \mathrm{O}$ Emissions from Coated and Uncoated Fertilizers}

The highest mean $\mathrm{N}_{2} \mathrm{O}$ flux was observed on the first day in the Urea treatment $\left(1140 \mu \mathrm{g} \mathrm{m}^{-2} \mathrm{~h}^{-1}\right)$, whereas Aminaex $\left(60.5 \mu \mathrm{g} \mathrm{m}^{-2} \mathrm{~h}^{-1}\right)$ and Biodrix $\mathrm{N}\left(57.9 \mu \mathrm{g} \mathrm{m}^{-2} \mathrm{~h}^{-1}\right)$ exhibited significantly lower $\mathrm{N}_{2} \mathrm{O}$ fluxes at that time and did not differ between one another $\left(p=1.0000\right.$; Figure 9). The differences between the mean $\mathrm{N}_{2} \mathrm{O}$ fluxes of all three fertilizers were significant at each sampling date $(p<0.0001)$, except for days 0 and 20. The release of $\mathrm{N}_{2} \mathrm{O}$ by Aminaex and Biodrix $\mathrm{N}$ was similar over the course of the 20 days $(p=0.9778)$, with the maximum $\mathrm{N}_{2} \mathrm{O}$ flux detected at day 10, ten days later than that observed in the Urea treatment. In addition, this maximum $\mathrm{N}_{2} \mathrm{O}$ flux from Aminaex and Biodrix $\mathrm{N}$ was lower by $55 \%$ and $38 \%$, respectively, compared to Urea. On the other hand, although the cumulative $\mathrm{N}_{2} \mathrm{O}$ flux difference after 20 days was not significant between the three fertilizers $(p=0.1504)$, Aminaex emitted $8 \%$ more $\mathrm{N}_{2} \mathrm{O}$ than Urea, while Biodrix emitted $17 \%$ more than Urea (Table 4).

Table 4. Cumulative $\mathrm{N}_{2} \mathrm{O}$ efflux per treatment after 20 days.

\begin{tabular}{|c|c|}
\hline Treatment & Cumulative $\mathrm{N}_{2} \mathrm{O}$ Efflux $\left(\mathrm{mg} \mathrm{m}^{-2}\right)$ \\
\hline Aminaex & $154.0 \pm 6.6 \mathrm{a}$ \\
\hline Biodrix $\mathrm{N}$ & $171.0 \pm 3.8 \mathrm{a}$ \\
\hline Urea & $142.2 \pm 9.5 \mathrm{a}$ \\
\hline Control & $39.8 \pm 3.4 b$ \\
\hline
\end{tabular}

Means ( \pm standard deviation) were separated using Tukey's least significant difference test $(\alpha=0.05)$. The same letter indicates non-significant differences among treatments.

Mean $\mathrm{CO}_{2}$ emissions from fertilized pots were significantly higher than the unfertilized control $(p<0.0001)$ (Figure 10). In addition, the difference among fertilized pots (Aminaex, Biodrix N, and Urea) was not significant for the entire duration of the experiment (20 days; $p=0.6622$ ). The highest $\mathrm{CO}_{2}$ efflux in the fertilized pots averaged $15.4 \mu \mathrm{mol}$ $\mathrm{CO}_{2} \mathrm{~m}^{-2} \mathrm{~s}^{-1}$ and was observed on day 7. On the same day, the $\mathrm{CO}_{2}$ efflux in the control treatment was $2.74 \mu \mathrm{mol} \mathrm{CO} \mathrm{m}^{-2} \mathrm{~s}^{-1}$.

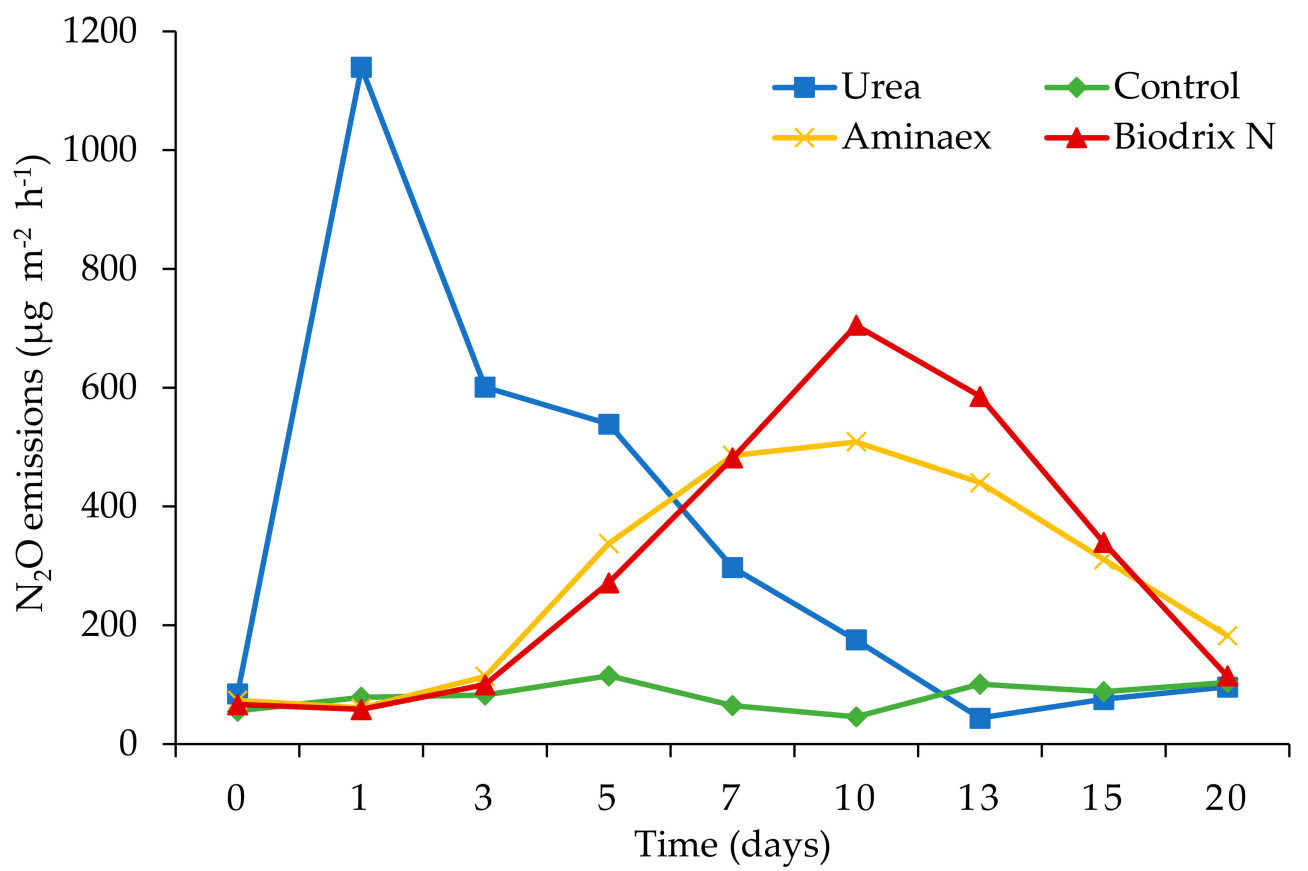

Figure 9. Variations in $\mathrm{N}_{2} \mathrm{O}$ efflux $\left(\mu \mathrm{g} \mathrm{m} \mathrm{m}^{-2} \mathrm{~h}^{-1}\right)$ at the soil surface over time (days) for the Aminaex, Biodrix $\mathrm{N}$, Urea, and control treatments. Error bars represent standard errors. 


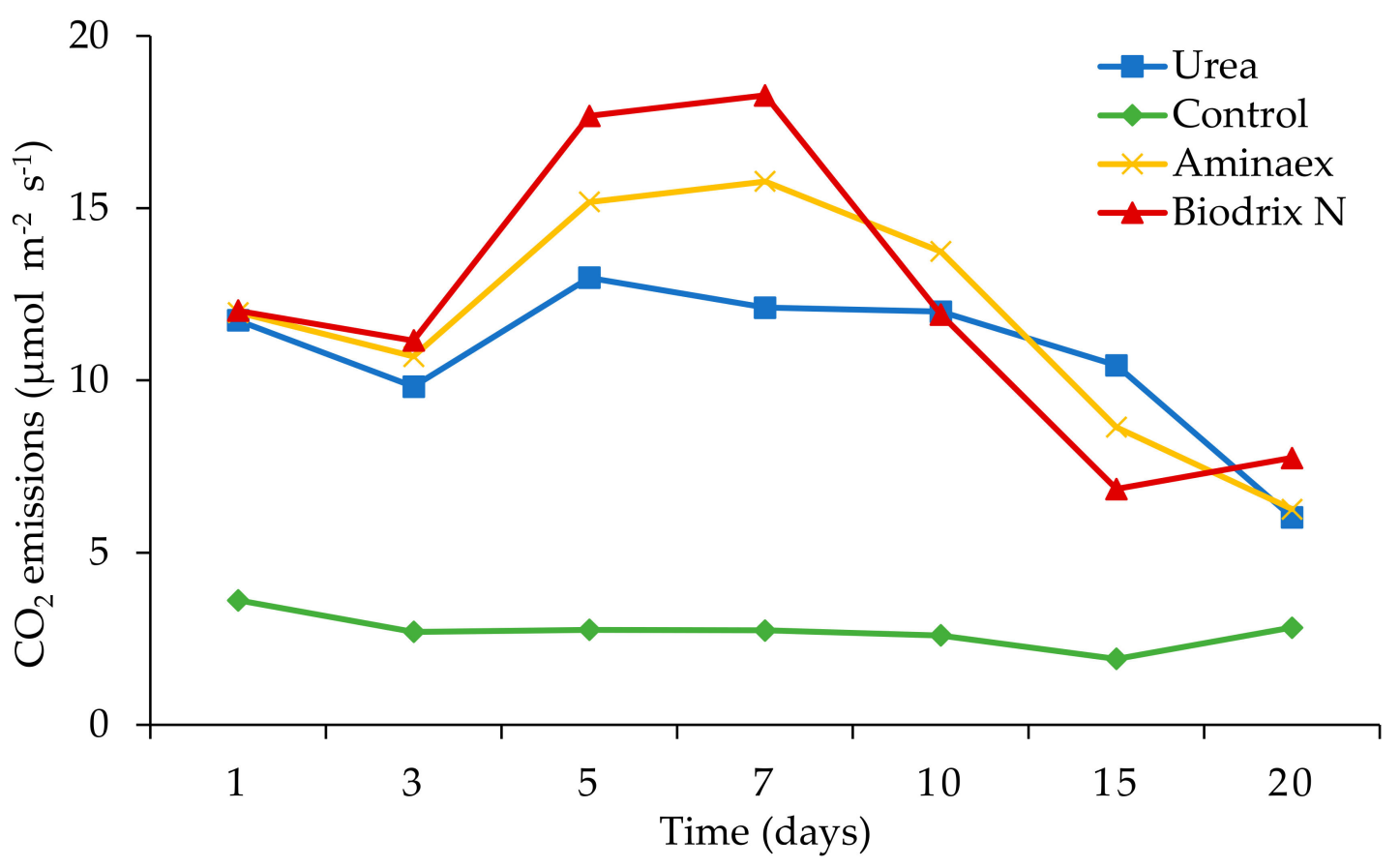

Figure 10. Variations in $\mathrm{CO}_{2}$ efflux $\left(\mu \mathrm{mol} \mathrm{m} \mathrm{m}^{-2} \mathrm{~s}^{-1}\right)$ at the soil surface over time (days) for the Aminaex, Biodrix N, Urea, and control treatments. Error bars represent standard errors.

\section{Discussion}

Despite some differences between the fertilizers coated with biodegradable polymers and the uncoated fertilizers, the use of polymers did not negatively affect the release of mineral nutrients in a water solution and in peat-based substrates under optimal solubilization conditions. However, the shape factors of the polymer-coated particles were slightly lower than those of the conventional fertilizers. This may be due to the structural characteristics of the coating such as thickness and uniformity between particles. Coating thickness likely varies among particles and on different areas of the same particle [31]. This lack of coating uniformity slightly decreased the shape factor ratio, which was significantly lower for coated fertilizers than conventional fertilizers for the three nutrients (N-P-K).

The coated fertilizers were solubilized after $24 \mathrm{~h}$ in a demineralized water solution. The biodegradable polymer coating is therefore relatively soluble and did not impede the release of mineral nutrients. Regarding the release kinetics of nitrogen in a relatively wet peat-based substrate (volumetric water content of $60 \%$ ), the Biodrix $\mathrm{N}$ fertilizer released $34 \%$ less urea and $\mathrm{N}$-urea than Urea (uncoated control) after $2 \mathrm{~h}$. This difference disappeared after one day. This could be considered a positive feature, given that conventional urea is quickly solubilized when water is not a limiting factor and the biodegradable coating inhibits the instant solubilization of urea. In practice, this coating could be used as an immediate source of certain mineral nutrients and to partially protect against leaching losses, particularly in the event of heavy rainfall. Applying coated fertilizers to the soil may lengthen the period of protection and increase the gradual release of mineral nutrients.

The effect of coated fertilizers on substrate $\mathrm{pH}$ and electrical conductivity was the same as that of uncoated or conventional fertilizers. Both coated and uncoated urea increased substrate $\mathrm{pH}$. As protons are used up during urea hydrolysis, the environment is alkalinized, but $\mathrm{pH}$ will eventually decrease and the environment will be acidified in the long term [6]. As such, soil enrichment with soluble salts during the 10-day experiment coincided with the progressive release kinetics of mineral elements in coated and uncoated fertilizers. Therefore, the composition of the biodegradable polymer coating did not affect the physicochemistry of the soil solution, contrary to other coating materials known to 
modify the soil solution's $\mathrm{pH}$ or salinity, thereby inhibiting the uptake of mineral nutrients by plant roots [32,33].

Leaching from the $\mathrm{S} 1$ peat-based substrate (without compost) contained high quantities of $\mathrm{N}-\mathrm{NH}_{4}$ but little amount of $\mathrm{N}-\mathrm{NO}_{2}+\mathrm{NO}_{3}$. These results suggest that nitrification did not occur, possibly indicating low microbial activity in the substrate. This was confirmed by low microbial respiration rates in the substrate $\left(0.6 \mu \mathrm{mol} \mathrm{CO} \mathrm{Cm}^{-2} \mathrm{~s}^{-1}\right)$. The coating, therefore, delayed leaching by gradually releasing mineral nutrients, which then reduced the maximum amount of mineral nitrogen leached. Although the leaching period was longer with coated fertilizers (with a smaller and later peak than that of Urea), cumulative nitrogen leaching in the form of ammonium by Aminaex and Biodrix $\mathrm{N}$ was reduced by $40 \%$ and $26 \%$, respectively, after 20 days, in comparison with the nitrogen $\left(\mathrm{N}^{-\mathrm{NH}_{4}}\right)$ leaching observed in the Urea treatment.

In the second substrate (S2), the addition of compost led to increased microbial activity, with average respiration rates in the unfertilized control of $2.7 \mu \mathrm{mol} \mathrm{CO} \mathrm{Cm}^{-2}$ $\mathrm{s}^{-1}$ (compared to $0.6 \mu \mathrm{mol} \mathrm{CO} \mathrm{Cm}^{-2} \mathrm{~s}^{-1}$ for S1). N-NH 4 was therefore nitrified, which increased the quantity of leached nitrates compared to the $\mathrm{S} 1$ substrate. The quantities of $\mathrm{N}-\mathrm{NO}_{2}+\mathrm{NO}_{3}$ were high in the Urea treatment during the early days of the experiment due to the rapid hydrolysis of Urea and the immediate availability of $\mathrm{N}-\mathrm{NH}_{4}$. Furthermore, an accumulation of ammonium was observed in the S2 substrate, possibly due to (i) high water content $\left(0.60 \mathrm{~cm}^{3} \mathrm{~cm}^{-3}\right)$, which would have limited the availability of oxygen needed for ammonium nitrification; or (ii) a large quantity of ammonium ions in the substrate, which inhibited Nitrobacter activity [6]. Leached solutions from the Aminaex and Biodrix $\mathrm{N}$ treatments contained more $\mathrm{N}-\mathrm{NH}_{4}$ and less $\mathrm{N}-\mathrm{NO}_{2}+\mathrm{NO}_{3}$ than those from the Urea treatment during the first 5-6 days. Under the same edaphic conditions, Aminaex and Biodrix $\mathrm{N}$ released mineral nutrients slowly compared to Urea. With less $\mathrm{N}-\mathrm{NH}_{4}$ in the substrate (due to the accumulated leaching mentioned above), ammonium nitrification was delayed, which also reduced nitrate leaching. Cumulative nitrate leaching was reduced by approximately $54 \%$ with Biodrix $\mathrm{N}$ and by $41 \%$ with Aminaex in comparison with Urea. These results are in line with those obtained by other studies examining the effect of coated fertilizers on nitrate leaching. Among these, Wilson et al. [34] found that polymer-coated urea significantly reduced nitrate leaching and increased nitrogen use efficiency. Similar results were obtained by Zvomuya et al. [35] in a study on the use of polyolefin-coated urea in potato crops.

The $\mathrm{N}_{2} \mathrm{O}$ flux emitted by the Urea treatment reached a maximum value on the first day due to the abundance of nitrates in the soil. This is supported by the quantities of $\mathrm{N}-\mathrm{NO}_{2}+\mathrm{NO}_{3}$ observed in the substrate during the leaching experiment (carried out under the same conditions). $\mathrm{N}_{2} \mathrm{O}$ fluxes then decreased, in parallel with a depletion of nitrates from the peat substrate and an accumulation of $\mathrm{N}-\mathrm{NH}_{4}$ produced by urea hydrolysis. A 10-day delay in peak $\mathrm{N}_{2} \mathrm{O}$ efflux with the coated fertilizers Aminaex and Biodrix $\mathrm{N}$ relative to Urea was also observed. This delay was due to the small quantities of nitrates in the peat substrate during the early days of the study. However, Aminaex and Biodrix $\mathrm{N}$ emitted $\mathrm{N}_{2} \mathrm{O}$ over a longer period than the Urea treatment, which contributed to a higher cumulative $\mathrm{N}_{2} \mathrm{O}$ flux after 20 days for the two coated fertilizers compared to the Urea treatment. Several studies have demonstrated the efficiency of urea polymerization in reducing $\mathrm{N}_{2} \mathrm{O}$ emissions [36,37]. In our case, coating urea with biodegradable polymers did not lead to a reduction in cumulative $\mathrm{N}_{2} \mathrm{O}$ emissions. This may be due to the physicochemical conditions of the substrate, which affect denitrification, such as the accumulation of ammonium or the low initial $\mathrm{pH}$ of the soil.

The small $\mathrm{CO}_{2}$ fluxes observed in the unfertilized (control) treatments are attributable to lower heterotrophic soil microbial respiration rates, likely limited by low nitrogen levels in the control substrate relative to the fertilized pots. The average daily $\mathrm{CO}_{2}$ flux was, however, similar for the treatments containing Aminaex, Biodrix N, and Urea; the same quantity of nitrogen fertilizer was used for all treatments. The addition of compost increased the C:N ratio, thereby improving microbial activity, which increases the rate of 
denitrification [38]. In the unfertilized pots (control), $\mathrm{N}_{2} \mathrm{O}$ fluxes were low, similarly to the lower $\mathrm{CO}_{2}$ fluxes observed in the same pots, indicating low microbial activity relative to the other treatments. The addition of nitrogen fertilizer increased heterotrophic respiration and $\mathrm{CO}_{2}$ efflux. This raised denitrification rates, suggesting higher biological activity among denitrifying bacteria [39].

Biodrix $\mathrm{N}$ and Aminaex had contrasting effects on the reduction of leaching and $\mathrm{N}_{2} \mathrm{O}$ emissions. Biodrix $\mathrm{N}$ was more effective than Aminaex in reducing nitrate loss via leaching, which dropped by $54 \%$ compared to Urea and by $13 \%$ compared to Aminaex. However, regarding the reduction of $\mathrm{N}_{2} \mathrm{O}$ emissions, Aminaex, and Biodrix $\mathrm{N}$ similarly delayed peak $\mathrm{N}_{2} \mathrm{O}$ flux, by 10 days, whereas Aminaex produced an $\mathrm{N}_{2} \mathrm{O}$ emission peak that was $17 \%$ lower than the one observed in the Biodrix $\mathrm{N}$ treatment. Although the Biodrix $\mathrm{N}$ and Aminaex fertilizers were both coated with biodegradable polymers, this variation is attributable to a difference in their coating compositions, which makes Aminaex more effective in reducing $\mathrm{N}_{2} \mathrm{O}$ emissions.

The results of the leaching experiment demonstrate that the quantities of leached ammonium and nitrates vary depending on substrate composition (with or without compost). Nitrate leaching was greater in the S2 substrate (containing 30\% compost) than the S1 substrate, which did not contain any compost. These results suggest that the addition of compost to organic crops could lead to significant nitrate leaching. Considering that compost increases the water holding capacity of the substrate [40], irrigation must be properly managed when using fertilizers coated with biodegradable polymers. In organic crops that use compost, for example, water volumes may be reduced or intervals between consecutive irrigations lengthened to minimize nitrate leaching and water use. Additionally, the effect of compost on the form of nitrogen present in the soil should be properly addressed, since nitrogen plays a direct role in crop development and growth. When nitrates are abundant in the soil, better root development is observed than when ammonium is abundant, since this nutrient supports aerial plant growth [41].

In a peat-based substrate with a relatively high volumetric water content $\left(\sim 0.60 \mathrm{~cm}^{3} \mathrm{~cm}^{-3}\right)$, the release kinetics of phosphorus by Biodrix P were the same as those of MAP. This result contrasts with other studies that have confirmed the effectiveness of phosphorus polymerization [42], particularly in gradually releasing mineral nutrients and reducing the absorption of $\mathrm{P}$ by soil colloids. In our case, this coating did not delay the release of phosphorus or subsequently reduce phosphorus loss through leaching [43]. This may be attributable to the high CEC and low $\mathrm{pH}$ of the peat substrate ( 4.3), which further decreased after the addition of phosphate fertilizers, as it is an ammonium fertilizer that acidifies the soil during nitrification. The low $\mathrm{pH}$ could have decreased the polymer's efficiency by saturating its exchange sites with $\mathrm{H}^{+}$ions, likely contributing to phosphorus solubilization [42]. These results were obtained in peat-based substrates with a low $\mathrm{pH}$, suggesting that this coated phosphate fertilizer may be less effective in soils with an acidic $\mathrm{pH}$. Future studies should be performed to determine the effect of Biodrix P in mineral soils.

Based on the initial concentrations of mineral nutrients contained in the potassium fertilizer, it can be seen that the solubilization of this coated potassium fertilizer was complete after $24 \mathrm{~h}$ (Table 2). These results indicate that the biodegradable polymers used for the coating did not adversely affect the release of potassium under optimal solubilization conditions. As for leaching, unlike nitrogen and phosphorus which constitute a major problem given their effects on the pollution of groundwater, human health, the proliferation of algae, and suffocation of aquatic life [6], there is no known negative effect of potassium on human health or the environment even at levels well above those commonly observed in soils and rivers [44].

\section{Conclusions and Research Needs}

Nitrogen fertilizers coated with biodegradable polymers (Aminaex and Biodrix N) inhibited the instant solubilization of Urea and reduced nitrate leaching by $41 \%$ and $54 \%$ 
compared to Urea. These two coated nitrogenous fertilizers (Aminaex and Biodrix N) delayed maximum $\mathrm{N}_{2} \mathrm{O}$ efflux by 10 days while also lowering the emissions peak. Biodrix $\mathrm{N}$ was the most efficient at reducing leaching, but the peak of $\mathrm{N}_{2} \mathrm{O}$ efflux was much lower for Aminaex than for Biodrix N. In practice, since nitrogen fertilizers are applied in intervals, these coated fertilizers can provide mineral nutrients over a long period, contrary to conventional urea (Urea) $[37,44]$. This will therefore reduce mineral nutrient leaching in the event of heavy rainfall and lower maximum $\mathrm{N}_{2} \mathrm{O}$ emissions in comparison with conventional urea.

Further work is needed to assess and better understand the potential of this new generation of nitrogen fertilizers. First in the presence of plants, to follow the synchronization of the release kinetics of the mineral nutrients of each fertilizer with the "timing" of the absorption of the mineral nutrients by the roots. Our study was able to confirm that a biodegradable polymer coating does not affect the physicochemistry of the soil solution, and therefore the absorption of mineral nutrients is not expected to be adversely affected. Furthermore, water was certainly not a limiting factor in the present study since the substrate used had a relatively high volumetric water content $\left(\sim 0.60 \mathrm{~cm}^{3} \mathrm{~cm}^{-3}\right)[23,24]$. Thus, to optimize the use of coated fertilizers, future experiments should be carried out to further assess the effect of different substrate water contents (low to high) combined with the same amount of coated and conventional fertilizers, on the kinetics of urea hydrolysis and the release of mineral nutrients, as well as on nitrate leaching and $\mathrm{N}_{2} \mathrm{O}$ emissions.

To further reduce $\mathrm{N}_{2} \mathrm{O}$ emissions, it would be interesting to explore the possibility of integrating nitrification inhibitors into the coating of these fertilizers. These inhibitors work by interfering with the activity of Nitrosomonas bacteria, which are responsible for converting the ammonium ion $\left(\mathrm{NH}_{4}{ }^{+}\right)$into nitrite $\left(\mathrm{NO}_{2}{ }^{-}\right)$, which is then converted into nitrate $\left(\mathrm{NO}_{3}\right)$. The efficacy of nitrification inhibitors has been demonstrated by several studies cited by Chen et al. [45].

In addition to reducing adverse environmental effects, the effect of these coated fertilizers on productivity and crop yields will determine the level of success in implementing this new technology. However, the consequences of agricultural practices aimed at reducing $\mathrm{N}_{2} \mathrm{O}$ emissions on crop yields remain largely unexplored [39]. Thus, it is essential to understand the quantitative relationship between crop yield, $\mathrm{N}_{2} \mathrm{O}$ emissions, and nitrate leaching to effectively guide strategies related to food security and climate change mitigation.

Author Contributions: Conceptualization, Y.M., S.P. and M.S.L.; methodology, M.S.L., S.P., Y.M., F.Z.B. and L.B.; validation, S.P. and M.S.L.; formal analysis, F.Z.B.; investigation, F.Z.B., S.P., M.S.L. and L.B.; resources, S.P., Y.M. and M.S.L.; data curation, F.Z.B. and L.B.; writing-original draft preparation, F.Z.B., M.S.L. and S.P.; writing-review and editing, F.Z.B., M.S.L., S.P., L.B. and Y.M.; visualization, F.Z.B., S.P., M.S.L. and L.B.; supervision, S.P., M.S.L. and Y.M.; project administration, S.P. and Y.M.; funding acquisition, Y.M. All authors have read and agreed to the published version of the manuscript.

Funding: Funding was provided to Fatima Benlamlih's graduate studies within the framework of an agreement concluded between the Governments of Morocco and Quebec. Additional funding for this research project was provided by the Direction de la recherche forestière (DRF) of the Ministry of Forests, Wildlife and Parks of the Government of Quebec as part of project no. 3321142332093: Optimization of the cultural practices affecting root insufficiency and the morphophysiological quality of the seedlings produced in forest nurseries (holder: Mohammed S. Lamhamedi).

Institutional Review Board Statement: Not applicable.

Informed Consent Statement: Not applicable.

Data Availability Statement: Data sharing does not apply to this article.

Acknowledgments: The authors would like to thank Mario Renaud, Carol Deblois and Denis Langlois from the Direction de la recherche forestière (DRF) of the Ministry of Forests, Wildlife and Parks of the Government of Quebec for their laboratory supervision and technical support, Sébastien Lange for his help with $\mathrm{N}_{2} \mathrm{O}$ flux measurements, and Marie Coyea from the Department of Wood and Forest Sciences at Laval University for her assistance with WinSeedle ${ }^{\mathrm{TM}}$. We thank two anonymous 
reviewers for their valuable comments and the editing staff for their suggestions that helped to improve this paper.

Conflicts of Interest: The authors declare no conflict of interest.

\section{References}

1. GIEC. Changements climatiques 2014: Rapport de synthèse. In Contribution des Groupes de Travail I, II et III au Cinquième Rapport D'évaluation du Groupe d'Experts Intergouvernemental sur l'Évolution du Climat; Pachauri, R.K., Meyer, L.A., Eds.; GIEC: Genève, Switzerland, 2014; pp. 60-79.

2. FAO. The Future of Food and Agriculture-Trends and Challenges; FAO: Rome, Italy, 2017; p. 180.

3. Zhu, J.H.; Li, X.L.; Christie, P.; Li, J.L. Environmental implications of low nitrogen use efficiency in excessively fertilized hot pepper (Capsicum frutescens L.) cropping systems. Agric. Ecosyst. Environ. 2005, 111, 70-80. [CrossRef]

4. Peña-Fleitas, M.T.; Gallardo, M.; Thompson, R.B.; Farneselli, M.; Padilla, F.M. Assessing crop N status of fertigated vegetable crops using plant and soil monitoring techniques. Ann. Appl. Biol. 2015, 167, 387-405. [CrossRef] [PubMed]

5. Cameira, M.; Mota, M. Nitrogen related diffuse pollution from horticulture production-mitigation practices and assessment strategies. Horticulturae 2017, 3, 25. [CrossRef]

6. Trenkel, M.E. Slow and Controlled-Release and Stabilized Fertilizers an Option for Enhancing Nutrient Use Efficiency in Agriculture, 2nd ed.; International Fertilizer Industry Association: Paris, France, 2010; p. 163.

7. Statistique Canada. Enquête sur les Expéditions d'Engrais, Bulletin de Service N²1-022-X; Statistiques Canada: Ottawa, ON, Canada, 2016; p. 15.

8. Stocker, T.F.; Qin, D.; Plattner, G.-K.; Alexander, L.V.; Allen, S.K.; Bindoff, N.L.; Bréon, F.-M.; Church, J.A.; Cubasch, U.; Emori, S.; et al. Technical Summary. In Climate Change 2013: The Physical Science Basis. Contribution of Working Group I to the Fifth Assessment Report of the Intergovernmental Panel on Climate Change; Cambridge University Press: Cambridge, UK; New York, NY, USA, 2013; pp. 37-53.

9. Syakila, A.; Kroeze, C. The global nitrous oxide budget revisited. GHG. Measur. Manag. 2011, 1, 17-26. [CrossRef]

10. Environnement Canada. Tendances en Matière d'Émissions au Canada, En81-18/2013F-PDF; Environnement Canada: Gatineau, QC, Canada, 2013; p. 95.

11. Do Nascimento, C.A.C.; Vitti, G.C.; de Abreu Faria, L.; Luz, P.H.C.; Mendes, F.L. Ammonia volatilization from coated urea forms. Rev. Bras. Ciência Solo 2013, 37, 1057-1063. [CrossRef]

12. Giroux, I.; Sarrasin, B. Pesticides et Nitrates dans l'eau Souterraine près de Cultures de Pommes de Terre-Échantillonnage dans Quelques Régions du Québec en 2008 et 2009; MDDEP, Direction du Suivi de l'état de l'Environnement, Centre d'Expertise en Analyse Environnementale du Québec: Québec, QC, Canada, 2011; p. 31.

13. Conseil des Académies Canadiennes. L'eau et l'Agriculture au Canada: Vers une Gestion Durable des Ressources en eau; Le Comité d'Experts sur la Gestion Durable de l'eau des Terres Agricoles du Canada, Conseil des Académies Canadiennes: Ottawa, ON, Canada, 2013; pp. 11-82.

14. Huang, J.; Xu, C.-C.; Ridoutt, B.G.; Wang, X.-C.; Ren, P.-A. Nitrogen and phosphorus losses and eutrophication potential associated with fertilizer application to cropland in China. J. Clean. Prod. 2017, 159, 171-179. [CrossRef]

15. Carson, L.C.; Ozores-Hampton, M. Factors affecting nutrient availability, placement, rate, and application timing of controlledrelease fertilizers for Florida vegetable production using seepage irrigation. HortTechnology 2013, 23, 553-562. [CrossRef]

16. Bley, H.; Gianello, C.; Santos, L.d.S.; Selau, L.P.R. Nutrient release, plant nutrition, and potassium leaching from polymer-coated fertilizer. Rev. Bras. Ciência Solo 2017, 41, e0160142. [CrossRef]

17. Eerd, L.L.V.; Turnbull, J.J.D.; Bakker, C.J.; Vyn, R.J.; McKeown, A.W.; Westerveld, S.M. Comparing soluble to controlled-release nitrogen fertilizers: Storage cabbage yield, profit margins, and N use efficiency. Can. J. Plant Sci. 2018, 98, 815-829. [CrossRef]

18. Azeem, B.; KuShaari, K.; Man, Z.B.; Basit, A.; Thanh, T.H. Review on materials \& methods to produce controlled release coated urea fertilizer. J. Control. Release 2014, 181, 11-21.

19. Naz, M.Y.; Sulaiman, S.A. Slow release coating remedy for nitrogen loss from conventional urea: A review. J. Control. Release 2016, 225, 109-120. [CrossRef]

20. Kalra, Y.P.; Maynard, D.G. Méthodes d'analyse des sols forestiers et des tissus végétaux. In Rapport d'Information NOR-X-319F; Forets Canada, Region Nord-Ouest, Centre de Foresterie du Nord: Edmonton, AB, Canada, 1992; pp. 1-116.

21. Timmer, V.R.; Parton, W.J. Monitoring nutrient status of containerized seedlings. In Proceedings of the Ontario Ministry of Natural Resources Nurseryman's Meeting, Thunder Bay, ON, Canada, 7-11 June 1982; Ontario Ministry of Natural Resources: Toronto, ON, Canada, 1982; pp. 48-58.

22. Lamhamedi, M.S.; Lambany, G.; Margolis, H.A.; Renaud, M.; Veilleux, L.; Bernier, P.Y. Growth, physiology and leachate losses in Picea glauca seedlings $(1+0)$ grown in air-slit containers under different irrigation regimes. Can. J. For. Res. 2001, 31, 1968-1980. [CrossRef]

23. Lamhamedi, M.S.; Labbé, L.; Margolis, H.A.; Stowe, D.C.; Blais, L.; Renaud, M. Spatial variability of substrate water content and growth of white spruce seedlings. Soil Sci. Soc. Am. J. 2006, 70, 108-120. [CrossRef]

24. Landis, T.D.; Tinus, R.W.; Barnett, J.P. Seedling nutrition and irrigation in the container tree nursery manual. In Agriculture Handbook: 674; USDA Forest Service: Washington, DC, USA, 1989; Volume 4, pp. 1-67. 
25. Rochette, P.; Bertrand, N. Soil-surface gas emissions. In Soil Sampling and Methods of Analysis; Carter, M., Gregorich, E.G., Eds.; CRC Press: Boca Raton, FL, USA, 2008; pp. 851-861.

26. Marble, S.C.; Prior, S.A.; Runion, G.B.; Torbert, H.; Gilliam, C.; Fain, G.B.; Sibley, J.; Knight, P. Effects of fertilizer placement on trace gas emissions from nursery container production. Hortscience 2012, 47, 1056-1062. [CrossRef]

27. Lange, S.F.; Allaire, S.E.; Van Bochove, É. Transfer of $\mathrm{CO}_{2}, \mathrm{~N}_{2} \mathrm{O}$ and $\mathrm{CH}_{4}$ to butyl rubber (polyisobutylene) septa during storage. J. Environ. Monit. 2008, 10, 775-777. [CrossRef]

28. DeKlein, C.; Harvey, M. Nitrous Oxide Chamber Methodology Guidelines; Ministry for Primary Industries: Wellington, UK, 2015; pp. 1-146.

29. Steel, R.G.D.; Torrie, J.H. Principles and Procedures of Statistics: A Biometrical Approach, 2nd ed.; McGraw-Hill: New York, NY, USA, 1980; pp. 20-90.

30. Lévesque, V.; Rochette, P.; Ziadi, N.; Dorais, M.; Antoun, H. Mitigation of $\mathrm{CO}_{2}, \mathrm{CH}_{4}$ and $\mathrm{N}_{2} \mathrm{O}$ from a fertigated horticultural growing medium amended with biochars and a compost. App. Soil Ecol. 2018, 126, 129-139. [CrossRef]

31. Azeem, B.; KuShaari, K.; Man, Z. Effect of coating thickness on release characteristics of controlled release urea produced in fluidized bed using waterborne starch biopolymer as coating material. Procedia Eng. 2016, 148, 282-289. [CrossRef]

32. Rose, R. Slow Release Fertilizers 101. In National Proceedings: Forest and Conservation Nursery Associations-1999, 2000, and 2001; Dumroese, R.K., Riley, L.E., Landis, T.D., Eds.; USDA Forest Service, Rocky Mountain Research Station: Ogden, UT, USA, 2002; pp. 304-308.

33. Shaviv, A. Environmental friendly nitrogen fertilization. Sci. China. Ser. C Life Sci. 2005, 48, 937-947.

34. Wilson, M.L.; Rosen, C.J.; Moncrief, J.F. Effects of polymer-coated urea on nitrate leaching and nitrogen uptake by potato. J. Environ. Qual. 2010, 39, 492-499. [CrossRef] [PubMed]

35. Zvomuya, F.; Rosen, C.J.; Russelle, M.P.; Gupta, S.C. Nitrate leaching and nitrogen recovery following application of polyolefincoated urea to potato. J. Environ. Qual. 2003, 32, 480-489. [CrossRef]

36. Hyatt, C.R.; Venterea, R.T.; Rosen, C.J.; McNearney, M.; Wilson, M.L.; Dolan, M.S. Polymer-coated urea maintains potato yields and reduces nitrous oxide emissions in a Minnesota loamy sand. Soil Sci. Soc. Am. J. 2010, 74, 419-428. [CrossRef]

37. Burton, D.L.; Zebarth, B.J.; Gillam, K.M.; MacLeod, J.A. Effect of split application of fertilizer nitrogen on $\mathrm{N}_{2} \mathrm{O}$ emissions from potatoes. Can. J. Soil Sci. 2008, 88, 229-239. [CrossRef]

38. Miller, M.N.; Zebarth, B.J.; Dandie, C.E.; Burton, D.L.; Goyer, C.; Trevors, J.T. Crop residue influence on denitrification, $\mathrm{N}_{2} \mathrm{O}$ emissions and denitrifier community abundance in soil. Soil Biol. Biochem. 2008, 40, 2553-2562. [CrossRef]

39. Van Zwieten, L.; Kimber, S.; Morris, S.; Downie, A.; Berger, E.; Rust, J.; Scheer, C. Influence of biochars on flux of $\mathrm{N}_{2} \mathrm{O}$ and $\mathrm{CO}_{2}$ from Ferrosol. Soil Res. 2010, 48, 555-568. [CrossRef]

40. Sorrenti, G.; Toselli, M. Soil leaching as affected by the amendment with biochar and compost. Agric. Ecosyst. Environ. 2016, 226, 56-64. [CrossRef]

41. Gagnon, J. Impact des Différentes Formes d'Azote (Urée, $\mathrm{NH}_{4}{ }^{+}, \mathrm{NO}_{3}{ }^{-}$) sur la Croissance des Plants et sur le Lessivage des Engrais. In Proceedings of the Session de Formation sur la Nutrition Minérale des Plants Forestiers, DRF-MRNF, Québec, QC, Canada, 15 April 2009; p. 72.

42. De Figueiredo, C.; Barbosa, D.V.; de Oliveira, S.A.; Fagioli, M.; Sato, J. Polymer-coated phosphate fertilizer and liming on the production and morphological parameters of corn. Rev. Cien. Agron. 2012, 43, 446-452.

43. Benlamlih, F. Évaluation d'une nouvelle génération d'engrais enrobés pour diminuer le lessivage des éléments minéraux et réduire les émissions de gaz à effet de serre $\left(\mathrm{N}_{2} \mathrm{O}\right)$. Master's Thesis, Université Laval, Québec, QC, Canada, 2019.

44. International Potash Institute. Le Potassium Un Élément Essentiel à la vie; International Potash Institute: Zug, Switzerland, 2012; p. 22.

45. Chen, J.; Lü, S.; Zhang, Z.; Zhao, X.; Li, X.; Ning, P.; Liu, M. Environmentally friendly fertilizers: A review of materials used and their effects on the environment. Sci. Total Environ. 2018, 613, 829-839. [CrossRef] [PubMed] 